\title{
DO TRABALHO À MEMÓRIA: UM ENSAIO SOBRE A IDENTIDADE DOS MINERADORES E O PROCESSO DE PATRIMONIALIZAÇÃO DA MINA BREJUÍ EM CURRAIS NOVOS/RN
}

\author{
Ângela Bezerra $^{1}$
}

Aqueles que escreveram a cidade, eternizados em praça pública, são as referências para as gerações futuras. São eles que têm autoridade para escrever e contar o seu passado. Quiçá, ainda teimam em escrever o futuro. (Walter Benjamin, 2012)

Sertão do Seridó, região central do Rio Grande do Norte, município de Currais Novos, 1943. Neste lugar e neste tempo começava a ser escrita uma nova história, não só de uma cidade, mas de toda uma região: era o início da exploração da scheelita ${ }^{2}$. O mundo acompanhava o acontecimento da Segunda Guerra Mundial, e os americanos precisavam se municiar, por isso a scheelita era tão importante para eles, por ser matéria prima importante para a fabricação de equipamentos bélicos. Sabedores da ocorrência do minério no Seridó - sertão do Nordeste do Brasil, haviam instalado um escritório para prospectar novas minas na região.

Com a descoberta da jazida de Currais $\operatorname{Novos}^{3}$, o Rio Grande do Norte passou a se destacar como o maior produtor do minério na América Latina. Praticamente toda a produção da scheelita em terras potiguares advinha inicialmente de duas minas situadas no município currais-novense: Barra Verde e Brejuí e, no final da década de 60, de uma terceira mina: Boca de Laje. As três exploravam um único corpo mineralizado (Cunha, 1988). O principal mercado consumidor, inicialmente, era a indústria bélica dos Estados Unidos.

\footnotetext{
${ }^{1}$ Universidade Federal do Rio Grande do Norte, Brasil

${ }^{2} \mathrm{O}$ nome scheelita é uma homenagem ao químico sueco Scheele, o primeiro a observar as propriedades da pedra mais pesada. A scheelita é um mineral de tungstênio (combinação das palavras suecas "tung" e "sten", que significam pedra pesada). Beneficiado, o tungstênio resulta em uma liga de alta resistência e robustez, por possuir o mais alto ponto de fusão - só se deforma quando submetido a uma temperatura acima de $3.378^{\circ}$. É matéria prima utilizada na indústria eletrônica, aeronáutica, siderurgia e na indústria de lubrificantes, armamentos e ferramentas. Também é utilizada como revestimentos de aeronaves e módulos espaciais (Relatório 76/77 - Grupo Tomaz Salustino).

${ }^{3}$ O povoamento da cidade começou em 1755, com a chegada do Coronel Cipriano Lopes Galvão, vindo de Igaraçu/PE, quando instalou uma fazenda de criação de gado na data de terra intitulada "Totoró". Acima da confluência dos rios Totoró e Maxinaré construiu, anos depois, outra fazenda com três novos currais, que passaram a ser designados de Currais Novos (Morais, 1998: 72).
} 


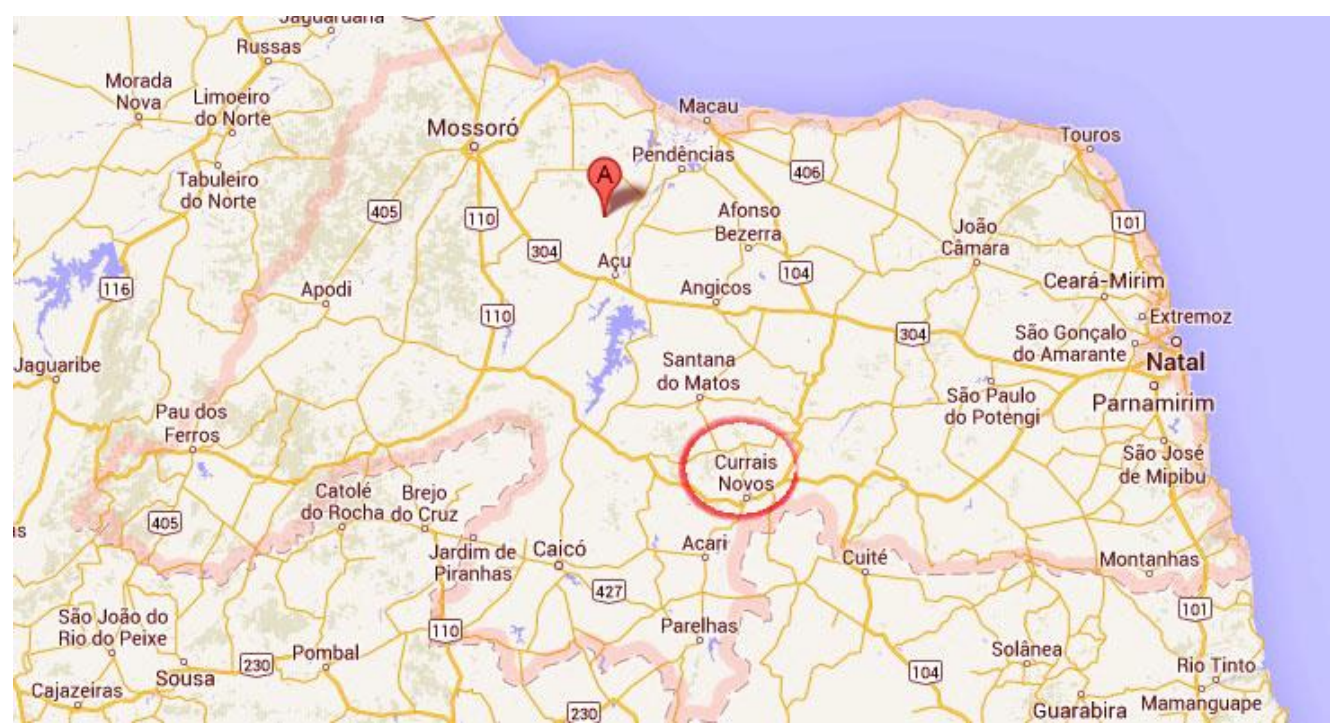

Figura 1: Mapa do RN com Currais Novos em destaque. Fonte: Google Mapas

A partir dali, a região se dedicaria à cata das "pedras pesadas", uma vez que, naquela época, das lavouras nada se colhia, castigadas que estavam pela estiagem. A mesma terra usada para o plantio das lavouras de algodão e para o pasto, atividades difundidas historicamente por aqueles sertões (Macêdo, 2012), abrigava também a scheelita. E, se por um lado, ajudava a germinar as identidades e o pertencimento dos produtores rurais à atividade agrícola enquanto estes a semeavam com milho, feijão e algodão, a mesma terra seguiria novamente servindo de abrigo para a colheita de outras identidades e pertencimentos com a retirada do minério. "A terra é o grande laboratório, o arsenal que proporciona tanto os meios e objetos do trabalho como a localização, a base da comunidade" (Marx, 1977b: 67). E só tem sentido falar da terra se as pessoas que lidavam com ela, sujeitos dessas identidades, forem destacadas.

A Mina Brejuí é a única administrada por um grupo familiar local, cujo patriarca, Tomaz Salustino, já era referência no criatório de gado e cultivo de algodão - dois importantes ciclos econômicos da região. A partir do momento em que o também desembargador ocuparia o papel de protagonista na outra ponta do tripé do desenvolvimento econômico do Seridó - o da exploração da scheelita -, se tornaria uma figura mítica. Foi atribuída a este personagem a autoria do "progresso" da cidade, em torno de quem giram as memórias guardadas daquela época, seja nos documentos escritos, nos registros audiovisuais ou no museu construído após o fechamento da mina. 
Em se tratando de uma empresa que nascia sob a chancela do coronelismo e do capitalismo, as relações de dominação pareciam se articular em nome do lucro do proprietário - um compadre (Faoro, 2001), representante de uma das oligarquias que dominavam politicamente e economicamente o Seridó. Por isso, importa investigar em que proporção a mina mudou a economia local e as relações sociais entre a elite política e os atores que atuavam na construção deste Brasil moderno: os trabalhadores.

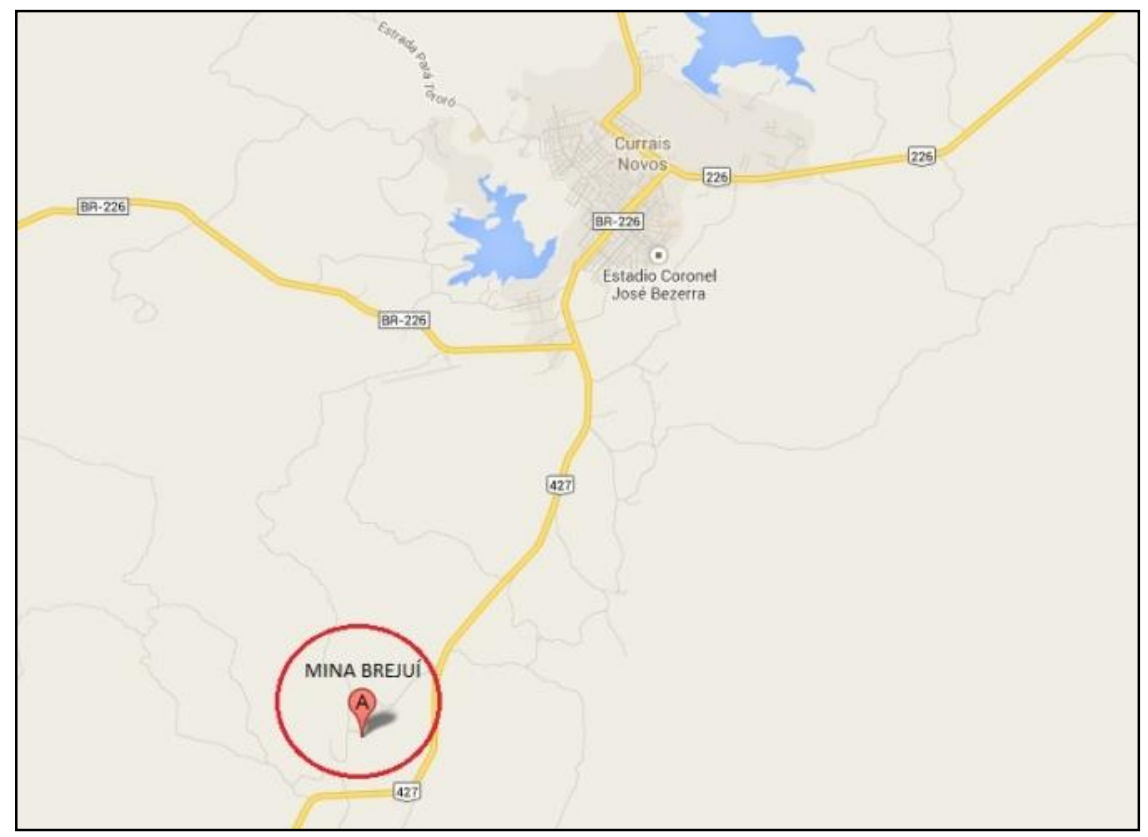

Figura2: Mapa de Currais Novos com a Mina Brejuí em destaque. Fonte: Google Mapas

A produção de scheelita, desde que começou na região do Seridó, apresentou sete picos de produção: 1945, 1953, 1958, 1971, 1975, 1977 e 1981, seguidos de intervalos de queda, devido às oscilações dos preços internacionais (Nesi, 1994). O principal mercado consumidor, inicialmente, era a indústria bélica dos Estados Unidos. Em 1982, porém, a produção de scheelita no Seridó decaiu radicalmente devido à forte entrada da China no mercado com seus baixos preços. As multinacionais não puderam mais operar na região, assim, as minas foram fechando uma a uma. A única que continuou resistindo foi a Brejuí, até que em 1990, interrompeu de vez as atividades.

Apesar da retomada da exploração da scheelita não só pela Mina Brejuí desde 2004, mas também pela vizinha Mineração Acauã e da possibilidade de outras minas de ouro e ferro começarem a operar em Currais Novos, é evidente a melancolia entre os interlocutores em relação ao passado glorioso vivido pela cidade e, especialmente, 
vivido pelos mineradores, quando a Mina Brejuí experimentou sua fase de maior produtividade e desenvolvimento.

O cenário atual nem de longe lembra aquele período, quando as minas de scheelita juntas empregavam em torno de quatro mil operários, quando a rotina de Currais Novos era marcada pelo vai e vem dos ônibus transportando os trabalhadores de casa para as minas, e a economia da cidade usufruía as benesses através, principalmente, do poder aquisitivo dos operários que garantiam a movimentação do comércio. A retomada da atividade, apesar de contar com mais de uma década, ainda se mostra muito tímida, se comparada com o auge da produção.

Enquanto a vida em Currais Novos segue pontuada pela expectativa de que um dia tudo isso volte a acontecer, a cidade cadencia sua rotina com as lembranças de sua melhor fase desde o ciclo do algodão ${ }^{4}$. Assim, proponho neste artigo, discutir sobre as memórias que restaram em decorrência do trabalho na mina e sobre o processo de patrimonialização experimentado pela cidade e pela vila operária, os símbolos que passaram a representar a identidade dos mineradores de Brejuí e sua consequente consciência de classe e, finalmente, as lembranças que restaram, sejam ao ar livre, sejam encerradas em museus ou memoriais. Comecemos tratando sobre as lembranças espalhadas pela cidade.

\section{A cidade e as lembranças do "tempo" da mina}

Quando as empresas de exploração da scheelita interromperam suas atividades entre o final da década de 1980 e o início da década de 1990, Currais Novos sentiu os impactos, especialmente em relação à Mina Brejuí. Os interlocutores são unânimes ao relembrar que "quando a mina parou, acabou com a cidade", que os trabalhadores que puderam foram embora em busca de outras oportunidades fora do Estado e "quem ficou aqui sofreu, ficou roendo os dedos, uns ficaram trabalhando em sitio, tirando lenha, trabalhando em olaria...". Segundo o diretor da Mina Brejuí, Reno Bezerra, a população que era de 50 mil habitantes, caiu para 42 mil com o fechamento das empresas, as consequentes demissões e o inevitável êxodo, que a exemplo de La Grand-

\footnotetext{
${ }^{4}$ Mais sobre a cultura do algodão no Seridó, ver Macêdo, 2012.
} 
Combe, também desintegrou redes familiares, de parentesco, de vizinhança, de colegas de trabalho e de amigos (Eckert, 2012: 65).

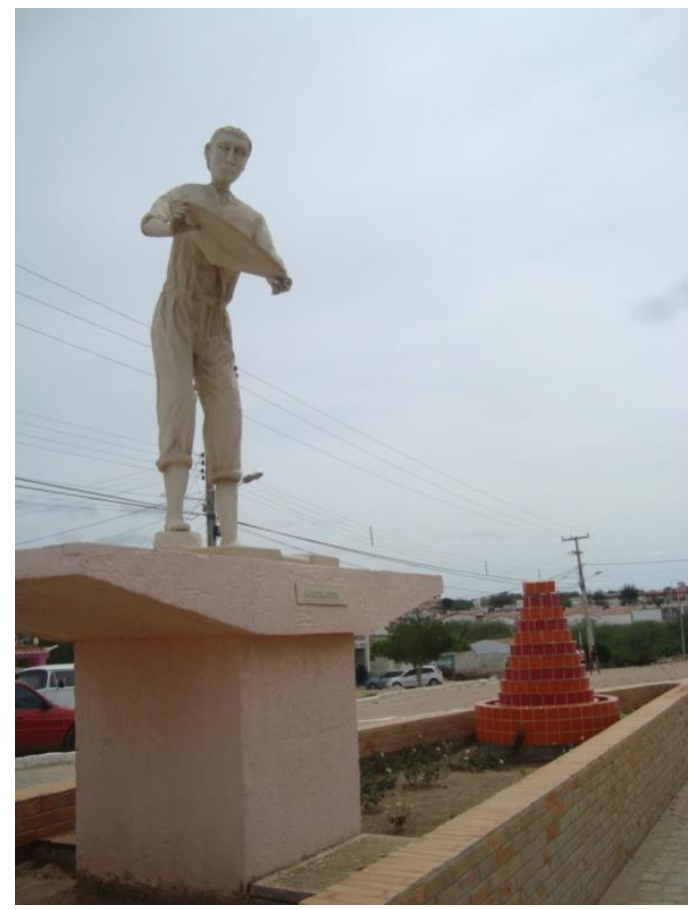

Figura 3: Estátua de minerador. Fonte: Arquivo pessoal da autora

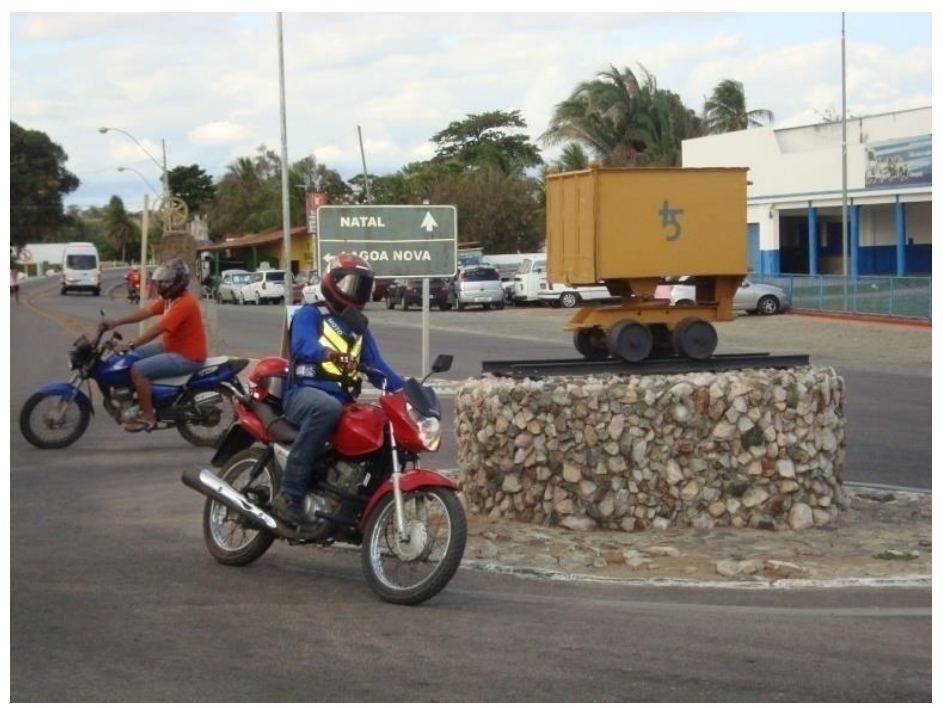

Figura 4: Vagonete instalado em rotatória da cidade. Fonte: Arquivo pessoal da autora 


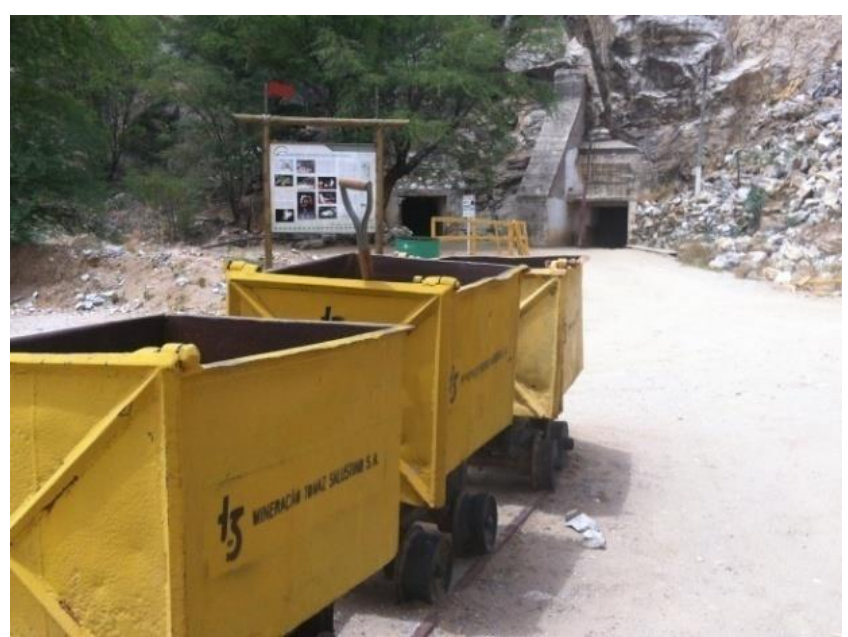

Figura 5: Parque Temático da Mina Brejuí. Fonte: Arquivo pessoal da autora

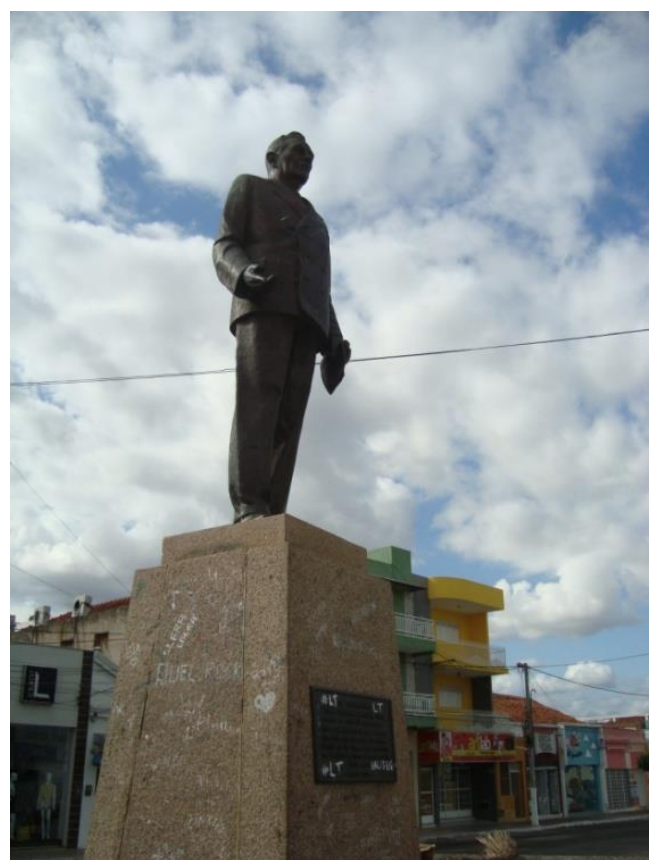

Figura 6: Estátua de Tomaz Salustino na praça que leva o seu nome. Fonte: Arquivo pessoal da autora

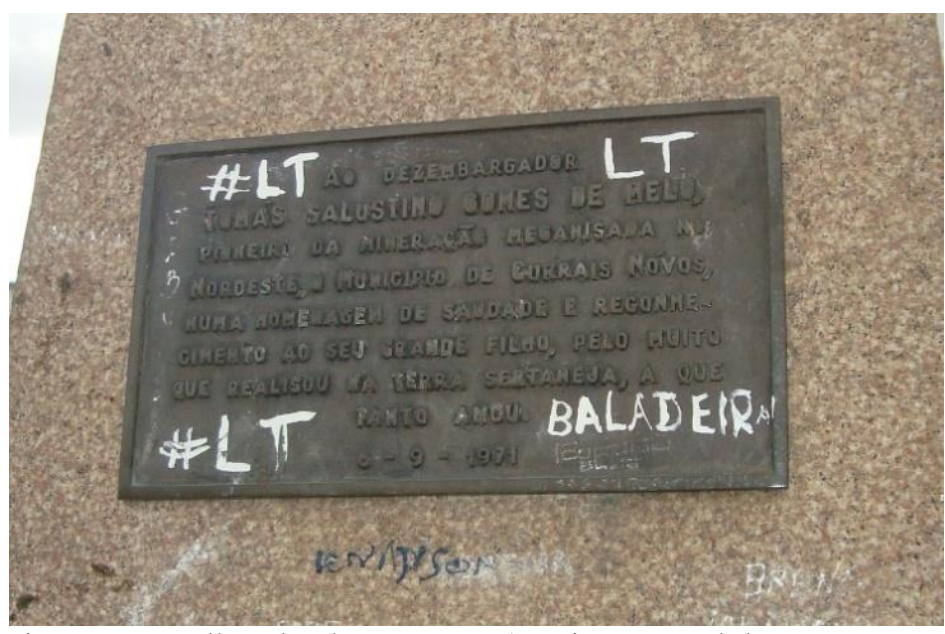

Figura 7: Detalhes da placa. Fonte: Arquivo pessoal da autora 
Currais Novos então, esvaziada dos seus heróis mineiros, pareceu necessitar preencher os espaços deixados em aberto, assim, se revestiu de símbolos que fazem referência à atividade: na entrada da cidade foi erguida uma estátua de um minerador; nos principais cruzamentos da cidade, foram instaladas vagonetes (com a logomarca da Mina Brejuí) - equipamentos utilizados para transportar o minério para fora dos túneis. Tais elementos surgiram em conjunto com a transformação da Mina Brejuí em parque temático em 2002, iniciativa da família Salustino visando atrair turistas interessados em conhecer sua história e o processo de retirada do minério das profundezas do subsolo.

Os símbolos advindos com esta fase de pós-fechamento das minas passariam a conviver com os sinais e as memórias do "tempo de abundância" (Leite Lopes, 1976), que já integravam a paisagem da cidade antes, como a estátua em bronze de Tomas Salustino instalada na praça que leva o seu nome, inaugurada em 1971, cuja placa traz a seguinte inscrição: “Ao Desembargador Tomaz Salustino Gomes de Melo, pioneiro da mineração mecanizada no Nordeste, o município de Currais Novos, numa homenagem de saudade e reconhecimento ao seu grande filho, pelo muito que realizou na terra sertaneja, a que tanto amou". Outros elementos caracterizam o "progresso" trazido com a atividade de exploração da scheelita e, consequentemente, realizados por Tomaz Salustino, a quem, junto com o filho Sílvio Bezerra, os interlocutores atribuem a autoria da "evolução" pela qual passou a cidade desde a descoberta da scheelita naquelas serras.

\footnotetext{
A cidade agradeça ser a cidade que é à mineração Tomaz Salustino e a Dr. Silvio, filho do desembargador, foi quem mais construiu dentro dessa cidade, os melhores prédios daqui foi Dr. Silvio que fez, essa avenida, que se chama Silvio Bezerra, isso aí era uma serra, ele danou as máquinas da mineração, desdobrou tudo ali, fez aquela avenida, abriu rua, fez tudo, foi prefeito na cidade, foi um grande homem dentro da cidade, tudo, agradeça à mineração. $\mathrm{O}$ Tungstênio Hotel, um dos maiores da cidade, é da mineração, Banco do Brasil, um grande prédio, é da mineração, não sei se já venderam, mas era. E campo de futebol, tudo ele ajudava. (Joca da Barra Verde entrevista na casa dele no bairro Sílvio Bezerra, em out/13)
}

Joca da Barra Verde funde em uma única entidade a empresa e o filho de Tomaz Salustino, Sílvio Bezerra, o responsável, segundo ele, pelo “desbravamento" do "progresso" da cidade tanto enquanto diretor da mina, como prefeito. Foi o responsável também por erguer prédios, cuja propriedade é atribuída à mineração. Então, quer seja à frente da mina ou da prefeitura, Sílvio Bezerra foi um "grande homem”. Os argumentos usados por Joca da Barra Verde fazem eco entre os outros interlocutores, que também destacam os prédios do Tungstênio Hotel, do Banco do Brasil, do posto de saúde, como 
exemplos de um "progresso" trazido com a Mina Brejuí, já que todos foram construídos por Tomaz Salustino. Aqueles que escreveram a cidade, eternizados em praça pública, são as referências para as gerações futuras. São eles que têm autoridade para escrever e contar o seu passado. Quiçá, ainda teimam em escrever o futuro (Benjamin, 2012).

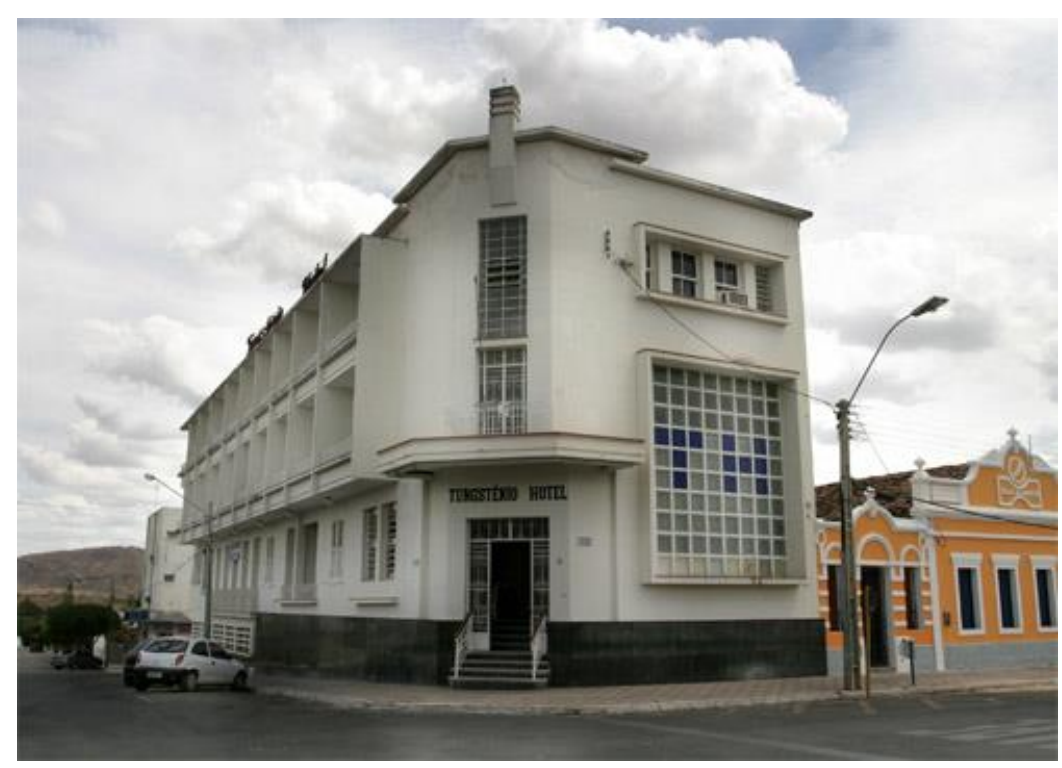

Figura 8: Tungstênio Hotel. Fonte: Arquivo pessoal da autora

Esses elementos se revelam como monumentos cuja utilização simbólica, por constituir o prestígio social, continuaram a demarcar a identidade coletiva daquela cidade. Tanto que em um trecho do hino de Currais Novos (lei no 771, 21 de dez. de 1976), esses feitos são eternizados como marcos de progresso: "Teus hospitais, institutos/ A estudantada vibrante/ Minerações, novas ruas/ Parecem gritar: Avante!” (Letra: Antônio Quintino Filho. Música: Francisco das Chagas Bezerra).

Em seu depoimento, Joca da Barra Verde também enfatiza as ruas abertas pelo filho do patrão, Sílvio Bezerra, que, à maneira como o pai fazia, colocou à disposição, em benefício da cidade, a estrutura da mina - no caso, as máquinas - para a construção de ruas, uma delas batizada com o seu nome. Não por acaso, é o mesmo discurso encontrado nos documentos pesquisados, como nas reportagens publicadas tanto em nível local quanto nacional. Os moradores da cidade, entre eles os mineradores, naturalizaram, assim, a ideia de que o "progresso" de Currais Novos está ligado à existência de tais edificações e repetem os discursos oficiais. 
Há também outras interpretações dos entrevistados que complementam o conceito que têm sobre o "progresso": o fato de as minas terem sido as principais fornecedoras de vagas de emprego da região, o que contribuía para fazer movimentar a economia da cidade. "Tudo o que eles [os operários] pegavam era pra comprar uma coisa, pra investir na cidade. Os comerciantes também se deram bem e os operários alguma coisa arranjaram com a mineração” (Joca da Barra Verde - minerador). “A Mina Brejuí já foi apelidada de 'mãe de família', porque nunca atrasou o pagamento, pagava pouco, mas nunca atrasou o pagamento, era a única renda que tinha na cidade" (José Milton minerador).

Os mais velhos, que viveram o início da exploração da scheelita, relembram como era a cidade antes do advento da mina: havia apenas a rua principal, a Rua Lula Gomes, onde ficava localizada a igreja, a Praça Cristo Rei e o mercado público, que futuramente seria derrubado para dar lugar à Praça Tomaz Salustino, como recorda Gentil Cortêz, 82 anos:

Eu fico meio assim porque tiraram aquele mercado dali. Ali era conhecido como Maria Carestia, era muito divertido. O mercado era em frente à casa de Dr. Tomaz. Aí fez um Banco do Brasil do outro lado, aí o negócio foi melhorando". "A família Salustino tem muito a ver com o progresso da cidade, Dr. Tomaz é o grande benemérito daqui da cidade, que cresceu em função dos valores dele (José Gilvan do Nascimento, 56 anos).

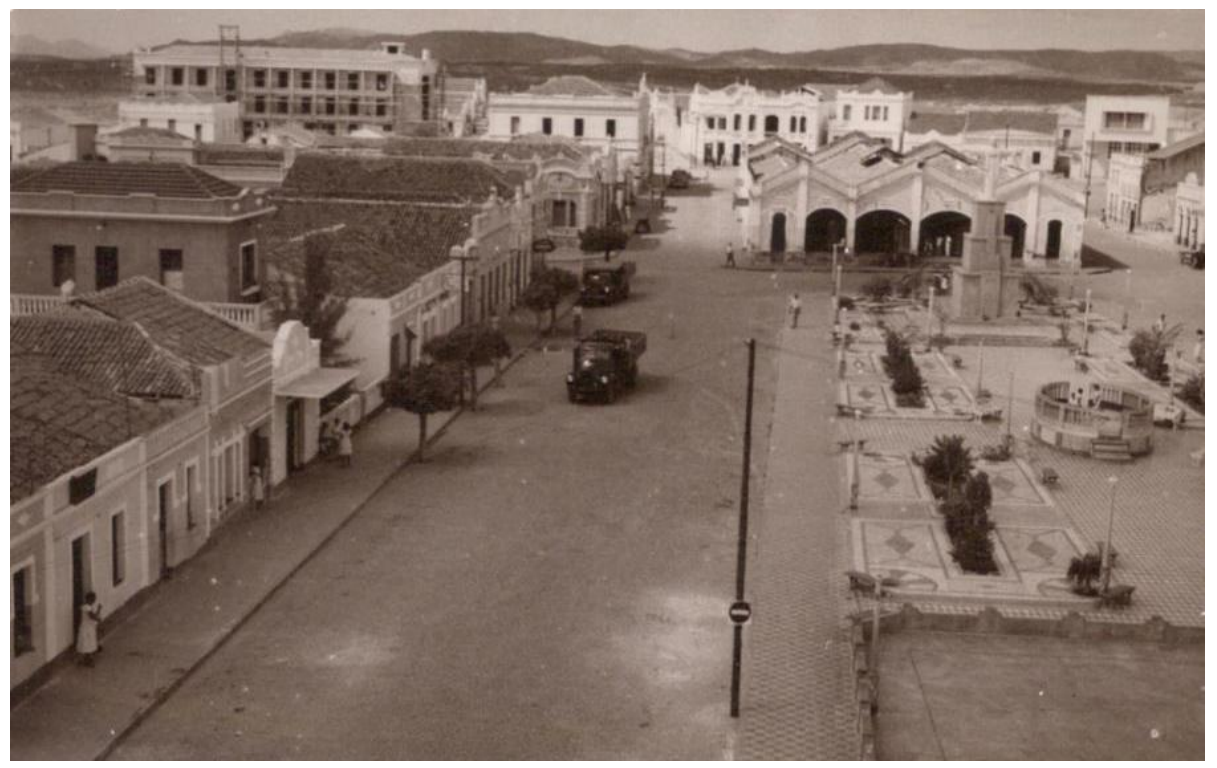

Figura 9: Currais Novos no início dos anos 1940. Fonte: Raimundo Bezerra 


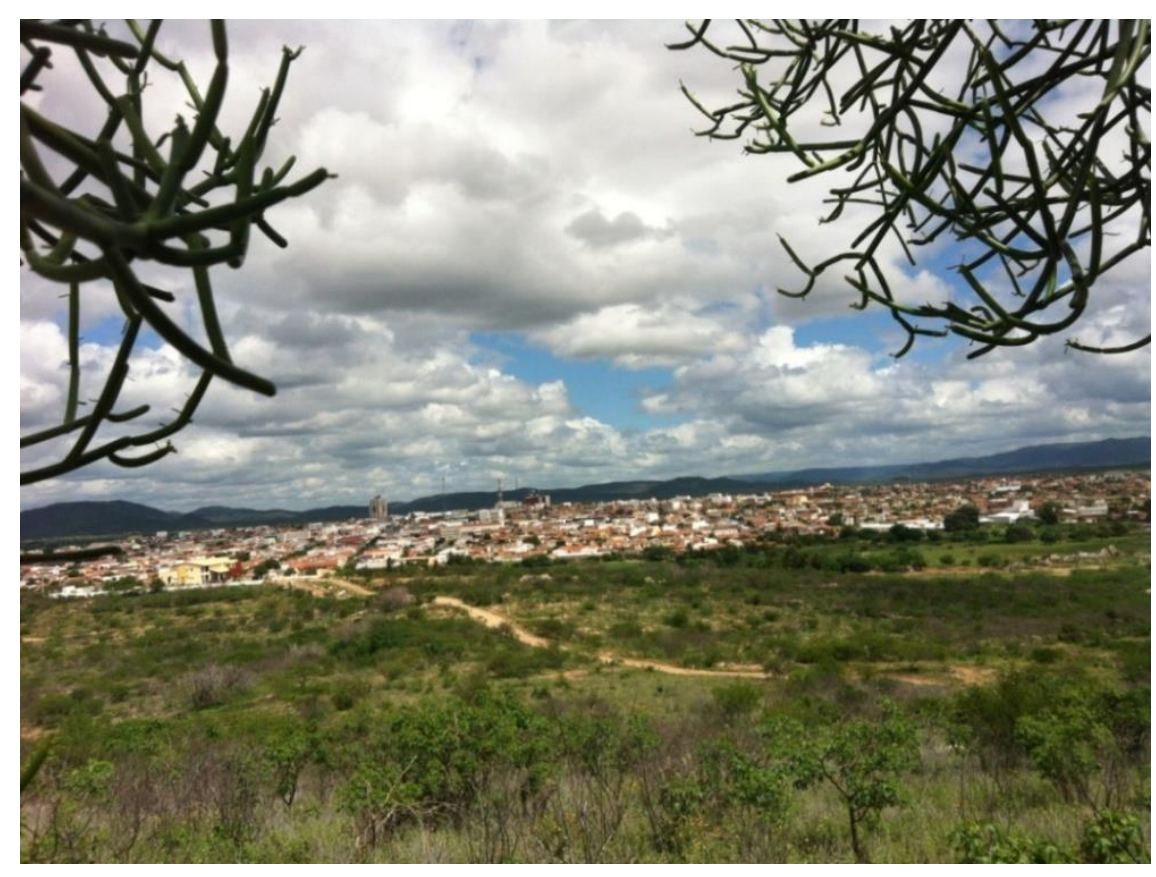

Figura 10: A cidade de Currais Novos hoje. Fonte: arquivo pessoal da autora

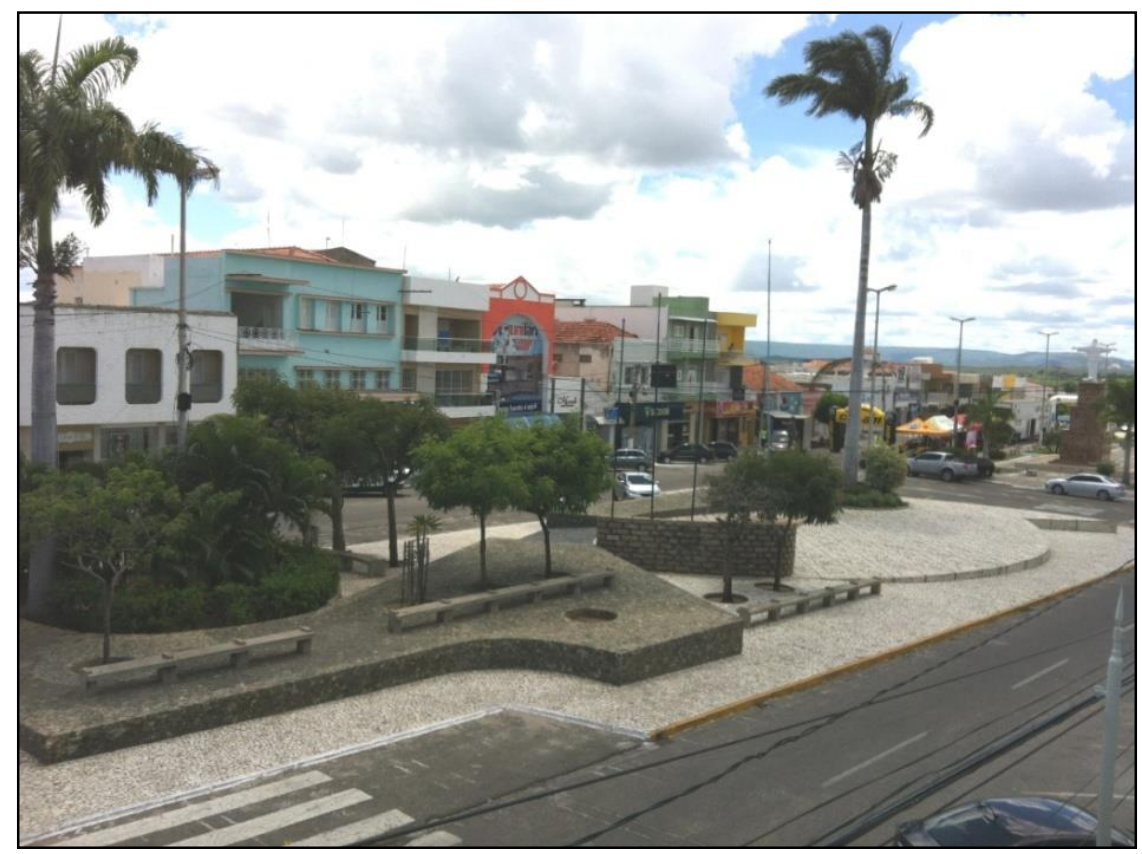

Figura 11: Praça Tomaz Salustino. Fonte: Arquivo pessoal da autora

Na figura 09, o mercado público, que Seu Gentil relembra, se chamava "Maria Carestia", ainda ocupa o local onde seria futuramente construída a praça Tomaz Salustino (figura 11). Ao fundo, à esquerda, ainda na figura 09, é possível ver o Tungstênio Hotel já em construção. O centro da cidade, que antes era residencial, teve 
com o tempo as casas transformadas em pontos comerciais, como é possível comprovar na figura 11. A figura 10, que representa a cidade atualmente, dá um pouco da dimensão do tamanho a que chegou.

O reflexo de o quanto a vida da cidade girava em torno da economia gerada pela scheelita está na memória de quem viveu o período em que a feira livre era o termômetro que media o volume de dinheiro que circulava na região. Como relembra Elisbão Silva, 66: "a feira era grande, começava de manhãzinha, se chamava até a Feira do Bacurau, que ia até 7 da noite, a feira livre de Currais Novos já foi grande”. Ora os interlocutores exaltam o patrão (Tomaz Salustino ou Sílvio Bezerra) como o responsável pelo desenvolvimento da cidade, ora exaltam os mineradores, em um sincronismo, que nivela os papéis de cada um neste processo, como reforça Elisbão: “Currais Novos cresceu muito com essas minerações, ela tá do jeito que tá hoje, agradeça às minerações quando funcionava com muitos operários que trabalharam lá."

Currais Novos, então para eles, chegou ao nível de crescimento que alcançou, graças tanto às minerações, em especial à Mina Brejuí, quanto aos mineradores de uma forma que eles se sentem participantes desta história. E a possibilidade de que a atividade volte a crescer é compartilhada pelo diretor da mina, Reno Bezerra, 70 anos, que diz, porém, ser cedo para medir a importância da empresa para a cidade. Para ele, este é um processo que está em andamento e deve continuar ainda por mais tempo, não só devido às reservas ${ }^{5}$ do minério inexploradas, mas também por que outras atividades podem ser agregadas, como a fabricação de cimento, um sonho que ele gostaria de ver realizado. O conceito de "progresso" para ele, também está relacionado à mudança provocada na cidade em função da "sorte" que o avô teve ao encontrar a scheelita em suas terras e de entender o valor daquele minério. Pergunto qual a importância para ele de ser detentor daquela história.

Primeiramente pela condição de participante, não a minha pessoa, mas os meus familiares. Em segundo lugar o fato de a exploração da scheelita ter alavancado o desenvolvimento e o progresso de Currais Novos. Só para você ter uma ideia, uns 10 anos atrás a mina parou de funcionar, assim como as outras minas também e parece-

\footnotetext{
${ }^{5}$ De acordo com o Relatório 76/77 do Grupo Salustino, as reservas do distrito scheelitífero situado no centro-oeste do RN e PB chegavam a 250.000 toneladas. Na área da Mina Brejuí eram de 70.000 toneladas. Porém, em entrevista publicada Tribuna do Norte em 2010, o então diretor da mina, Carlos Dutra, afirmou que havia mais de 23 milhões de toneladas de minério nas jazidas de Brejuí Disponível no site: http://tribunadonorte.com.br/noticia/a-mina-possui-um-bom-potencial/155099. Acesso em 03/03/14.
} 
me que a ordem de habitantes que diminuiu aqui foi de 8 mil a 10 mil e hoje ela está se recuperando disso.

A mina trouxe um progresso em termos de arrecadação, e um segundo progresso que eu acho que é mais importante que é justamente abrir a cabeça das pessoas para a instrução, atualização e assim por diante. Se você comparar uma fotografia de 1942 com uma fotografia atual, há uma diferença aqui.

Nós estamos completando 70 anos de existência e espero que quem continuar bote mais outro tanto, porque em termos de reserva, nós temos um pouco menos da metade do que já estamos. (Reno Bezerra - diretor da Mina Brejuí - entrevista na casa dele, na cidade de Currais Novos em out/13)

Assim como Reno, entre os operários também há a certeza de que a mineração é a atividade que seguirá guiando os rumos da vida em Currais Novos, mesmo que a Mina Brejuí seja vendida, como Reno deixa transparecer a possibilidade. Eles veem com otimismo a retomada da produção da scheelita e da chegada da exploração de outros minérios. A mina de ouro, se abrir, vai ter muito emprego, e o ouro tá fundo. É grupo de fora, de estrangeiros, aí movimenta muita coisa. Queria ter meus 20 anos que eu ia me socar lá e trabalhar mais 15 anos (Francisco Jerônimo, 69).

Assim, ao contrário de acompanharem os acontecimentos como expectadores, os mineradores se sentem incluídos e participantes ativos deste processo de retomada de crescimento da cidade.

A rotina do trabalhador mineiro, no entanto, repercute, como não poderia deixar de ser, nas práticas familiares, tanto como forma de influência para as gerações mais novas que se estimulam a seguir o ofício dos mais velhos - alimentadas pela imagem de herói, como também, por outro lado, leva ao compartilhamento do medo entre os membros da família. A família mineira de Brejuí, mantida por seu "pai de família", acompanha, junto com ele os receios do ofício, especialmente suas esposas e filhas, coadjuvantes nesta jornada.

\section{As famílias mineiras, suas mulheres e a vila operária}

Depois que se tornou empresa, a Mina Brejuí só contrataria os homens como operários, diferente da fase de garimpo em seu início, quando as mulheres trabalhavam junto com os homens na retirada do minério, assim como faziam no roçado (Woortman, 1991). Às mulheres, a partir de então, foi fechada a possibilidade de assumir emprego na linha de frente da mineração; algumas exceções foram consideradas, mas apenas para cargos na administração, como secretárias e telefonistas. Desde então, as esposas 
passariam a depender financeiramente do chefe de família, o operário provedor do lar e, conformadas com aquela situação, iriam em busca de algum reforço na renda, lavando roupa ou terceirizando algum outro serviço doméstico.

Margaret Mead constatou que, seja na divisão do trabalho, no vestuário, na atividade social e religiosa, às vezes apenas em alguns aspectos, outras vezes em todos eles, homens e mulheres são socialmente diferenciados e, cada sexo, como sexo, é forçado a conformar-se ao papel que lhe é atribuído (Mead, 1979: 24). Já era assim quando se tratava do trabalho agrícola - onde cada um tem as suas tarefas definidas (Woortman, 1991), e continuou da mesma forma no ambiente do garimpo - apesar de oferecer mais abertura para as mulheres que quisessem e pudessem se aventurar como donas de banquetas, e não seria diferente no novo cenário industrial da mina: aos homens cabia aceitar as condições oferecidas pela empresa e, às mulheres, restava o papel de donas de casa, condição aceita pelas famílias cujos chefes optaram por seguir trabalhando na mina.

A mesma situação se estenderia às filhas, também impossibilitadas para o trabalho na mina, diferente dos filhos homens, que ao contrário, eram encorajados pela empresa a seguir o mesmo ofício do pai. Assim como em La Grand-Combe (Eckert, 2012), a Mina Brejuí também estimulava a família voltada para o lar e à auto-reprodução da força de trabalho. Assim, a família nuclearizada (pai, mãe e filhos) era o ideal almejado, uma vez que seria voltada para a multiplicação da força de trabalho, que no caso em análise não requeria unicamente uma reprodução de suas habilidades, mas também e, ao mesmo tempo, uma reprodução de sua submissão à ideologia dominante por parte dos trabalhadores (Althusser, 1971: 132-133).

O trabalho na Mina Brejuí, assim como em La Grand-Combe, tornou-se o centro de gravidade dos projetos familiares, uma vez que a empresa também comandava os diferentes domínios da vida cotidiana, familiar e todas as instituições sociais interligadas (Eckert, 2012: 34). A postura da companhia era a mesma nos dois cenários: exaltava a família voltada para o lar como instituição moral sustentada pela empresa no que diz respeito à segurança moral espiritual e física e apoiava-se nas redes familiares e de parentesco para compor e recompor a mão de obra. $\mathrm{O}$ resultado foi uma organização social local fortemente estruturada em torno da família (Eckert, 2012: 32).

Tomo aqui como referência, o espaço da vila operária, onde, inicialmente as famílias dos operários residiriam e que sucedeu as barracas onde moravam os 
garimpeiros. Em conversas com as mulheres que encontrei na vila, todas seguem com suas famílias mantendo o vínculo com o local de moradia surgido em função do trabalho do pai e, consequentemente, do marido. É o caso de Maria Lúcia da Silva, 53 anos: o pai, a mãe, os irmãos e o marido, todos trabalharam na mina. $\mathrm{O}$ marido segue no ofício há mais de 20 anos: é um dos que optaram por continuar trabalhando mesmo depois de aposentado. Antes, trabalhava no engenho, mas depois que se aposentou foi atuar como garimpeiro no subsolo, recebendo por produção, "porque gosta e precisa", como aponta sua esposa: "do dinheiro daqui é que ele já formou um filho está formando uma filha, por isso ele trabalha”.

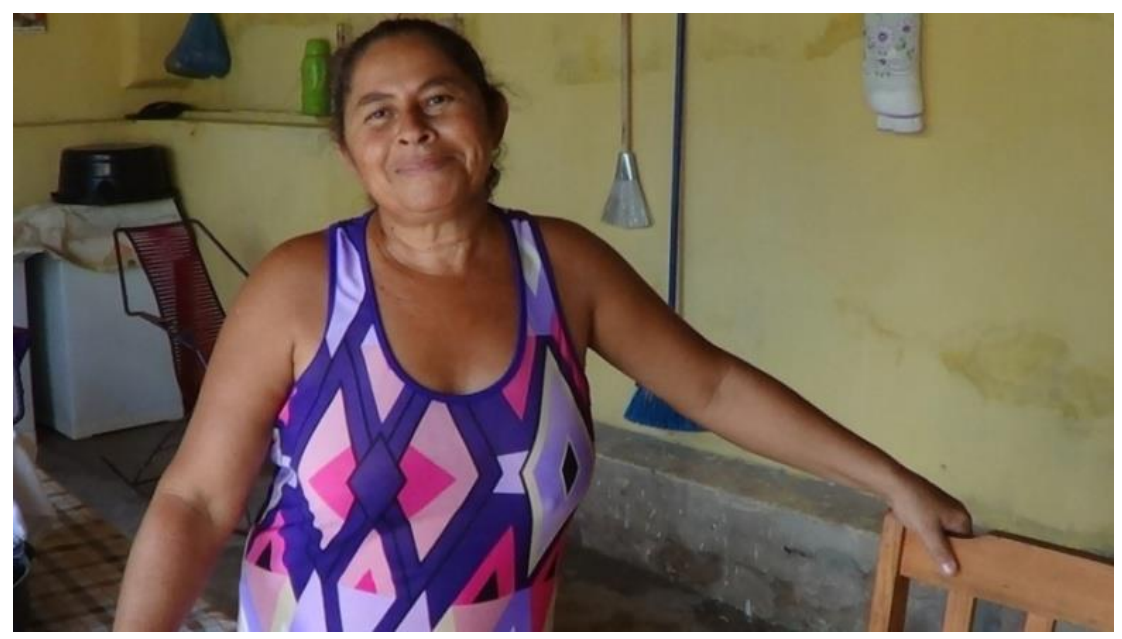

Figura 12: Maria Lúcia da Silva, 53 anos, sempre morou na vila operária. Fonte: Arquivo pessoal da autora

Lúcia não sabe ao certo o que o marido faz, e diz preferir continuar sem conhecer o local de trabalho dele porque tem medo: "o trabalho dele é muito perigoso, dentro de buraco, essas coisas, né, a gente acha perigoso, mas quer dizer que em todo canto é perigoso, mas lá é perigoso demais, e ele que já perdeu um cunhado aí dentro... [pausa]”. Mesmo assim, tanto para ela quanto para os filhos, o ofício do "dono da casa" é motivo de orgulho: por mais que os filhos peçam para o pai deixar o subsolo, não querem que ele saia da mina, "especialmente por causa da morada, eu comecei nas barracas e estou terminando na vila, é um orgulho muito grande”. A garantia da morada na vila permanece reforçando o dueto trabalho-teto, que é utilizado como instrumento de sedução eficaz pelas companhias para atrair e fixar a mão de obra anteriormente camponesa, confrontada com as dificuldades do trabalho agrícola (Eckert, 2012: 32). 
A morada na vila operária de Brejuí segue o mesmo preceito da morada que é negociada entre os grandes proprietários da terra e seus trabalhadores, que não se refere apenas à casa e ao pequeno pedaço de terra que o proprietário "dá" àqueles que trabalham em suas terras, mas inclui também a oferta de emprego e moradia dentro dos limites da propriedade. A moradia, portanto, de acordo com Marcos Lanna, deve ser entendida em situações assim, como uma "prestação total" à maneira de Mauss, prestação esta que parece englobar todas aquelas que constituem a relação entre proprietário e trabalhador (Lanna, 1995: 56). E se esta morada permanece importante, se deve ao fato de a casa ser uma categoria fundamental, como aponta DaMatta (1984). E esta categoria, seja qual for a forma específica em que se manifeste nos diversos tempos e lugares, tem a capacidade de englobar a lógica do mercado e do capital, completa Lanna (1995: 75).

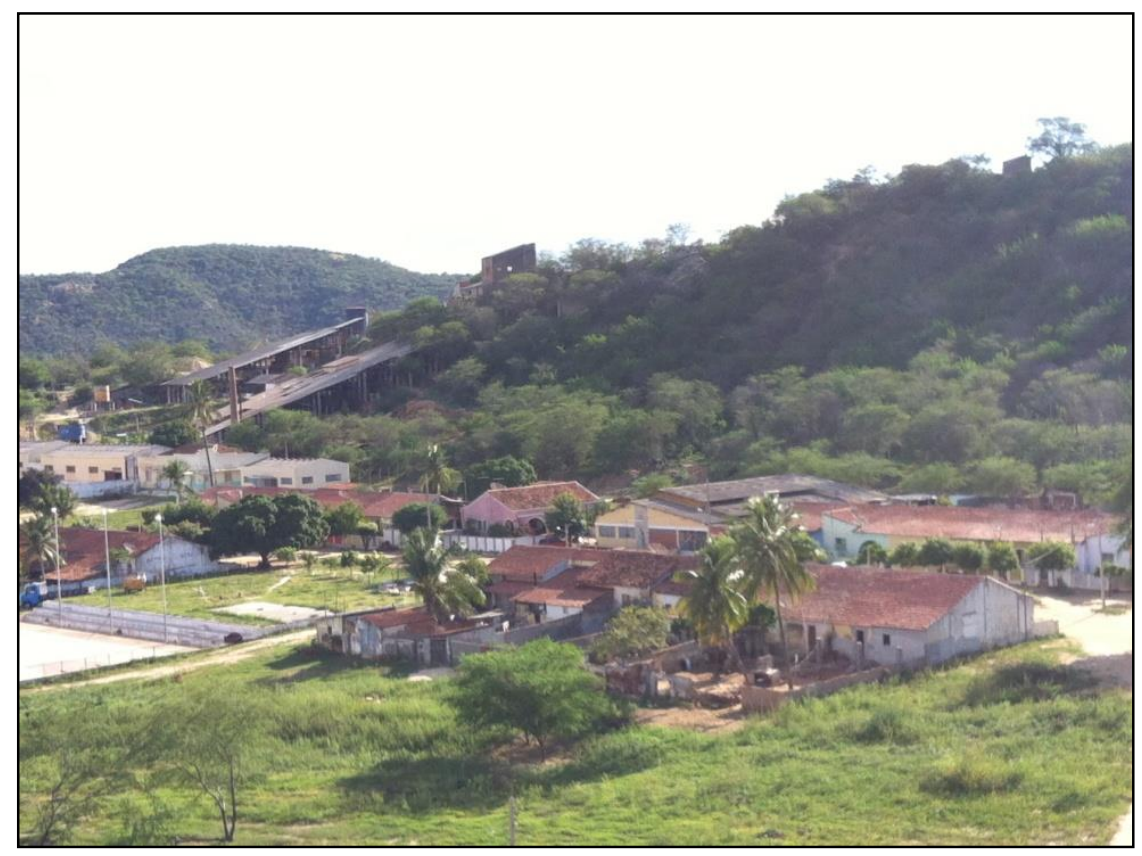

Figura 13: Vila operária de hoje. Fonte: Arquivo pessoal da autora

Durante o período em que a mina funcionou, os operários que moravam na vila não tinham qualquer custo com suas casas: não pagavam aluguel nem precisavam se preocupar com a manutenção, que era por conta da empresa. Mas depois que a mina fechou e alguns operários que moravam no local foram embora, a situação mudou: quem optasse por continuar na vila ou viesse a morar lá depois, teria que pagar um aluguel para garantir a manutenção das casas. Depois, com a retomada da atividade em 
2004, alguns operários voltaram a morar no local, estes, porém, não precisariam pagar a taxa, que segue sendo cobrada às outras famílias que não têm vínculo com a mina, e hoje varia em torno de $\mathrm{R} \$ 70,00$ segundo a direção da empresa. A prática é comum às indústrias que têm como política manter um controle estreito sobre a vida de seus operários como aponta Leite Lopes:

O fato de certas indústrias fornecerem casas a seus operários, em contrapartida seja de um aluguel geralmente descontado do salário, seja das obrigações econômicas e não econômicas geralmente não explicitadas em contrato, mas incorporadas ao comportamento dos operários como parte das regras do jogo, significa de fato uma interferência direta e visível da administração da fábrica sobre a vida extra-fabril dos trabalhadores (Leite Lopes, 1988: 17)

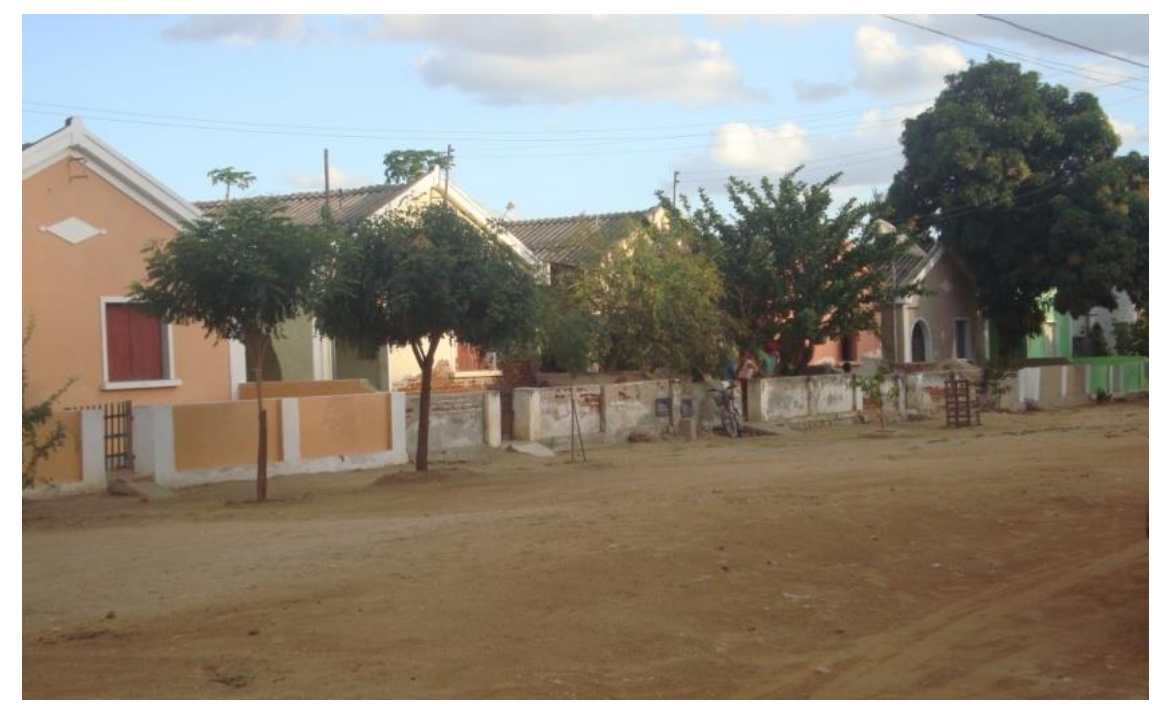

Figura 14: Detalhes da vila operária. Fonte: Arquivo pessoal da autora

Portanto, de uma forma ou de outra, os moradores da vila atualmente, permanecem mantendo alguma ligação com a mina, seja porque ainda trabalham, seja porque trabalharam, ou porque seus pais ou maridos já trabalharam. Assim, se a vila operária de Brejuí, foi no auge de sua produção, uma forma de a empresa imobilizar a força de trabalho através da moradia, como Leite Lopes (1976) observou entre as usinas açucareiras de Pernambuco, hoje permanece como um local onde o pertencimento ao espaço de trabalho dos entes daquelas famílias mineiras está representado. Um espaço que se perpetuou mineiro em sua essência, mantendo vivas as lembranças do tempo em que a empresa experimentou o seu auge. Um lugar, que, assim como Eckert verificou na 
vila operária de La Grand-Combe, funcionou como importante fonte de relações sociais e culturais e que seguiu direcionando a construção social do grupo de tradição (Eckert, 2012: 52).

As irmãs Ana Rosângela da Silva, 42 anos, e Deilma Rodrigues da Silva, 39 anos, são um bom exemplo. Filhas de ex-operário, elas se mantêm fortemente vinculadas à vila: Deilma permanece morando no local "porque meu pai trabalhava na mina, eu nasci e me criei aqui" e Ana Rosângela, apesar de morar na cidade, vai todos os dias para a vila, onde moram a sogra e a cunhada. Elas ainda têm mais dois irmãos que moram na vila: uma irmã cujo marido trabalha na mina e um irmão que também trabalha na mina. No dia em que conversei com as duas, Rosângela estava ajudando a Deilma a organizar uma festa surpresa para a filha da irmã, que completava 18 anos. Enquanto preparavam a comida e organizavam a cozinha, iam enumerando os motivos pelos quais se mantêm fortemente ligadas à mina e à sua vila operária e sobre as memórias que guardam a respeito do trabalho do pai.

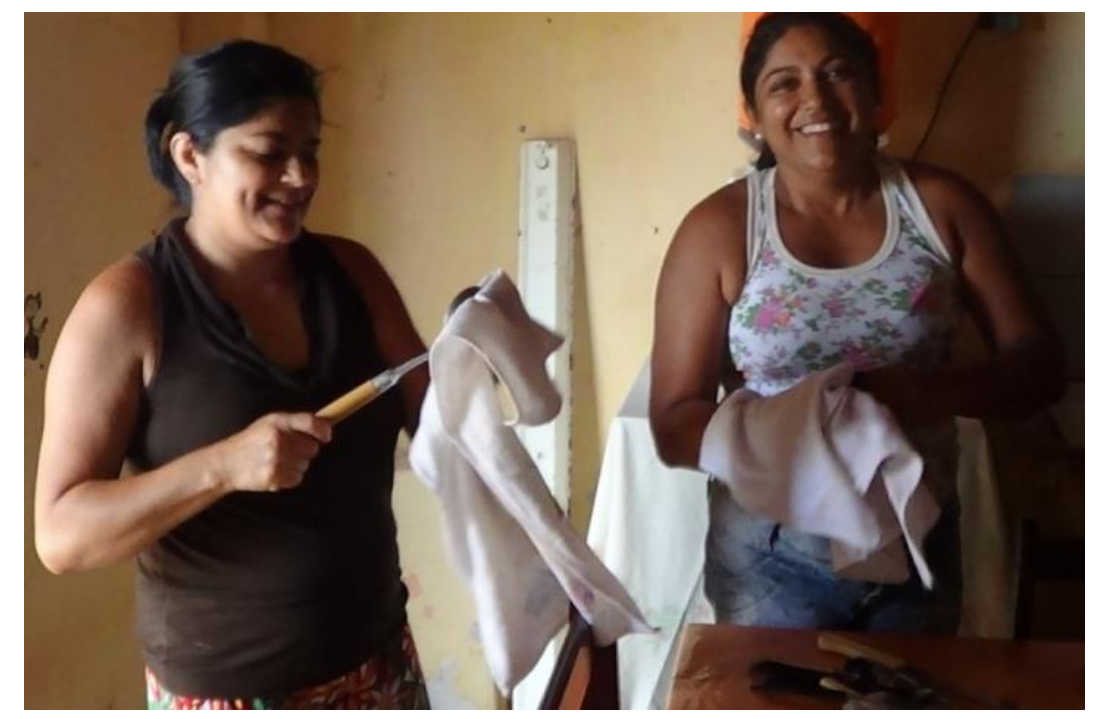

Figura 15: Ana Rosângela e Deilma, filhas de ex-operário. Fonte: arquivo pessoal da autora

Rosângela diz que achava bonito o trabalho do pai: "ele tinha nove filhos, era só uma pessoa trabalhando pra dar de comer aos nove filhos. Naquele tempo era tudo muito dificil". Para completar a renda, ela conta, as filhas lavavam roupa, inclusive as toalhas do escritório e do ambulatório da mina, ou então trabalhavam como empregadas domésticas em Currais Novos. A mãe "era do lar, quem lavava essas toalhas, era nós, 
as filhas moças, às vezes tinha festa aqui na mina e a gente vendia as coisas, ia trabalhar pra conseguir o dinheiro pra ir pras festas, tudo era mais dificil”.

As duas relembram a rotina de trabalho do pai: ele saía de casa às 6h e voltava às 14h ou "pegava" às $16 \mathrm{~h}$ e saía à meia-noite. "Ele trabalhava na lavagem da scheelita, saía de casa todo dia de botas, de farda e com uma touquinha pra trabalhar na mina". Foi assim, diariamente, durante 15 anos seguidos, até se aposentar. Depois, ele foi com a família morar na cidade e, mesmo alguns de seus filhos tendo feito o caminho inverso, retornando a morar na vila, o pai, elas contam, não costuma visitar o lugar onde morou por décadas: "ele prefere ficar na casinha dele mesmo". Deilma, cujo marido é funcionário da mina, conta que, em troca da moradia em uma das casas da vila, a família paga aluguel à empresa, que por sua vez, tem um acordo com os moradores sobre a manutenção da casa.

Optei por falar sobre a vila operária de Brejuí juntamente com as mulheres e, consequentemente sobre as famílias operárias, porque estes três temas se apresentaram conjuntamente durante a pesquisa de campo. Durante as visitas à vila, chamou atenção a presença de grupos de mulheres concentrados em frente às casas conversando, enquanto seus maridos estavam no trabalho ou na própria mina ou em outra empresa fora dali. São elas que dominam o espaço da vila enquanto os homens passam a maior parte do tempo fora, como é o caso de Maria Aparecida Ribeiro, 45 anos, cujo marido trabalha em outra cidade, Cajazeiras, como marteleteiro, função que também exerceu em Brejuí. Ela não sabe ao certo o que faz um marteleteiro, só sabe que é perigoso e diz ter medo que aconteça algo com o marido, assim como aconteceu com o pai, que morreu em um acidente na mina, onde trabalhava como guincheiro.

Aparecida passa os dias na vila contando o tempo que falta para o marido se aposentar: três anos. A falta de informação ou mesmo o desinteresse das mulheres sobre a profissão de seus maridos aparecem refletidos no silencio a que foram submetidas ao terem sido excluídas das atividades da mina e mantidas nos limites domésticos das casas da vila. Por ser um silêncio difícil de ser medido e que tende a representar um comportamento de subalternidade, segundo Spivak aponta, a relação entre mulher e silêncio, pode ser tecida por elas mesmas, como verificamos nos depoimentos desta pesquisa. Ao falar sobre a mulher como subalterna, a pesquisadora sugere a possibilidade de que a existência da coletividade em si mesma é persistentemente excluída mediante a manipulação da agência feminina (Spivak, 2003: 321). A agência 
das mulheres de Brejuí, neste sentido, foi mantida sob o mesmo controle que regeu e continua regendo o trabalho dos homens de suas famílias.

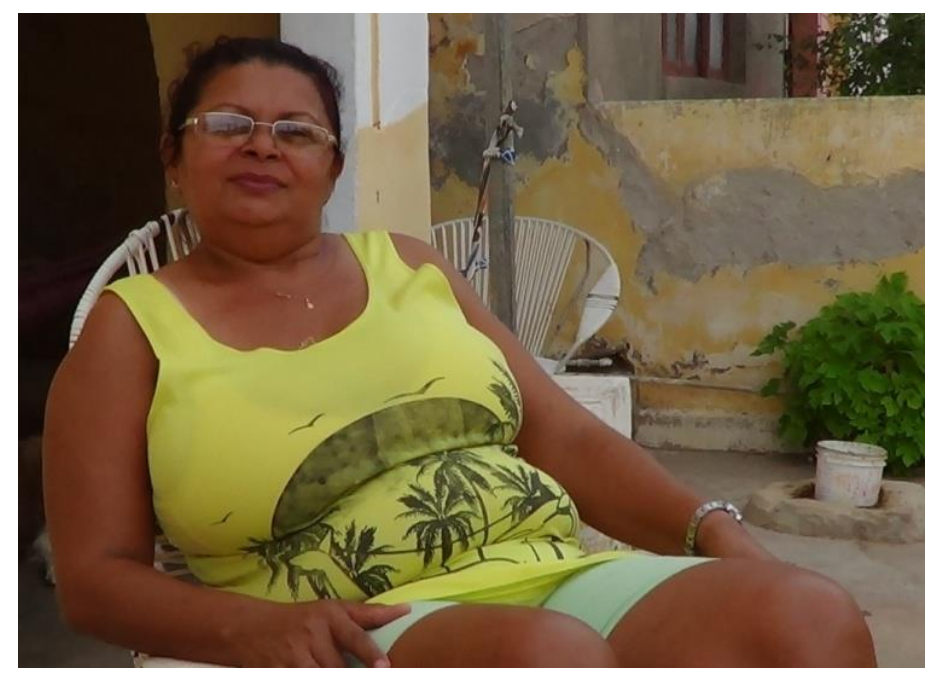

Figura 16: Maria Aparecida Ribeiro, 45 anos, filha de ex-operário. Fonte: Arquivo pessoal da autora

E é assim, nessa cadência, que segue a vida na vila operária de Brejuí: ritmada pela manutenção de laços de parentesco, de amizade e de práticas sociais que nasceram em um tempo de abundância, quando a empresa oferecia não só a morada atrelada ao trabalho, mas também outros benefícios como saúde, educação e lazer. No cenário atual, as rotinas são reconstruídas e reorganizadas, compassadas pelas mudanças experimentadas pela empresa que repercutiram não só no trabalho dos homens, os "pais de família”, como também no modo de vida das famílias da vila.

As mulheres que permanecem residindo lá mantêm fortes suas memórias em torno do trabalho de seus pais na mina, enquanto administram sua rotina atual acompanhando a mesma jornada de seus maridos e irmãos, desempenhando o papel de testemunhas, de detentoras das lembranças. A memória é entendida como uma construção social relativa ao passado, realizada através do uso da razão por um indivíduo ou por um grupo de indivíduos que interagem no presente (Santos, 2012: 166). Assim, aqueles grupos de mulheres que passam o tempo conversando em frente às casas na vila, seguem alimentados pelas lembranças do passado, cadenciando a vida do presente, assim como os operários - seus maridos, irmãos e pais - o fazem dentro dos túneis. Além da vila operária, os mineradores concentraram morada em ruas e bairros específicos, como os que trataremos a seguir. 


\section{Além da vila operária: o bairro e a rua dos mineradores}

Fora do território da vila operária, os mineradores se concentraram em bairros e ruas da cidade cuja vizinhança era composta em sua maioria por colegas de trabalho. Os locais de moradia funcionam assim como uma extensão da identidade dos trabalhadores: é onde convivem com os colegas nos horários de lazer e reforçam os laços de amizade e companheirismo. Desta forma, alguns loteamentos, conjuntos residenciais e bairros foram aparecendo para acomodar esse perfil específico de morador - os operários das minas -, como os conjuntos Promorar e IPE, que no auge da produção da scheelita, surgiram multiplicando suas casas populares na periferia da cidade. Muitos dos operários não só da Mina Brejuí, mas também das minas vizinhas, compraram ou alugaram casas lá.

Ao sair à procura de ex-funcionários da Brejuí fora dos domínios da vila, porém, nenhum dos interlocutores recomendou esses dois locais. A primeira indicação que chegou foi da Rua Baldômero Chacom, onde vive atualmente o pai das irmãs Ana Rosângela e Deilma. Elas disseram que naquele endereço moram muitos ex-mineiros. O pai delas não estava em casa, em compensação, conheci os amigos Elisbão Bezerra da Silva, mais conhecido como Bamba, de 66 anos, e Dinarte José da Fonseca, de 53 anos. Os dois jogavam baralho no bar que funciona nos fundos da casa de Elisbão, enquanto falavam sobre suas trajetórias na mina. Dinarte lamenta ter saído da empresa antes de completar o tempo para a aposentadoria, apesar de dizer que não se arrepende da decisão:

Saí na época da greve, eles deram a opção a quem quisesse sair, eles davam as contas com todos os direitos, eu saí, fui na ilusão de trabalhar fora, caí nessa vida e até hoje não me aposentei. Se eu tivesse ficado, hoje eu era aposentado. Todos os meus colegas estão aposentados, acho que o único que não se aposentou fui eu. (Dinarte José da Fonseca, de 53 anos entrevista no bar de Elisbão, na Rua Baldômero Chacon, Currais Novos)

Enquanto isso, Elisbão se diz tranquilo com os recursos advindos com a aposentadoria: comprou a casa onde mora, montou o bar e segue usufruindo o benefício mensal, mesmo que seja de apenas um salário mínimo. Ele relembra que durante os quase 20 anos em que trabalhou na mina, mesmo depois de aposentado, morou nas barracas que antecederam a vila operária. "Comecei a trabalhar lá solteiro, aí casei com aquela baixinha ali, criamos três filhos, todo mundo morava lá.” Depois, Elisbão 
foi em busca da casa própria: “Alguns colegas não fizeram isso não, tiravam o Fundo de Garantia e estruíam [desperdiçavam] o dinheiro bebendo e até hoje não têm casa".

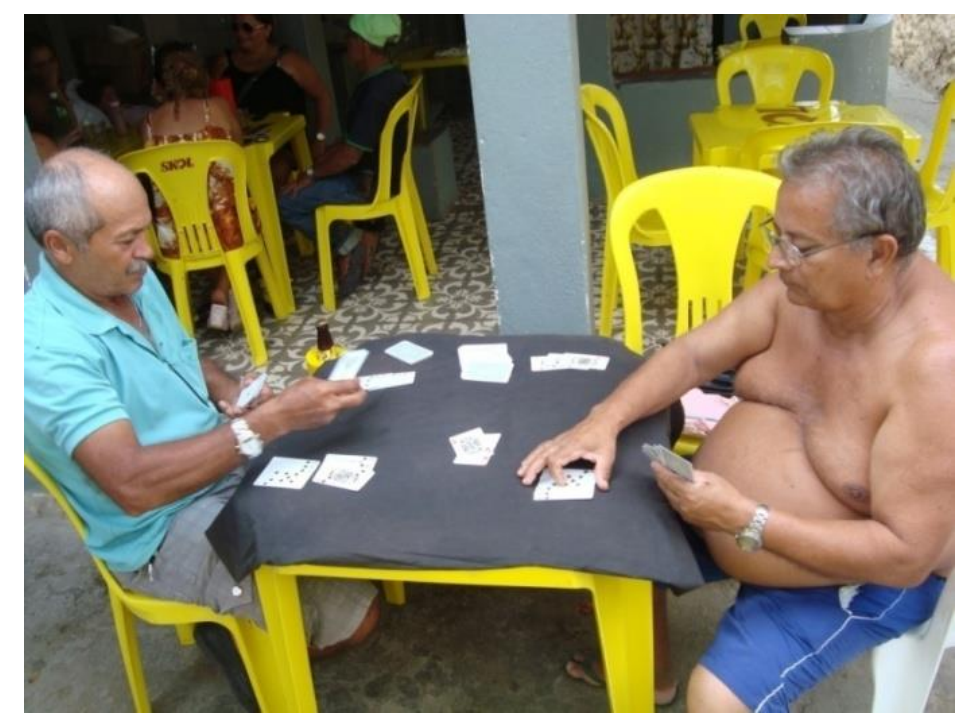

Figura 17: Elisbão Bezerra e Dinarte Fonseca. Fonte: Arquivo pessoal da autora

O bairro Silvio Bezerra, localizado na saída de Currais Novos, no caminho que leva às minas, também concentra um grande número de mineiros e ex-mineiros e, segundo Joaquim Ramos Pereira, entre os cerca de três mil moradores, $80 \%$ são trabalhadores e aposentados das minas: "onde você chegar, procure um marteleteiro, vai no bairro Silvio Bezerra que você encontra; procure um soldador, vai no bairro Silvio Bezerra que você encontra." Não é por acaso que no local moram tantos mineradores: teriam sido eles os fundadores.

O bairro surgiu por causa da mina, porque ficava todo mundo por aqui, a cidade há 30 anos era só da saboaria pra lá, pra cá não existia nada. Os funcionários que trabalhavam lá [na mina] começaram a construir as casas aqui pra ficar mais perto da mina, foi tipo apropriação, era um terreno vazio e o pessoal vinha morar aqui em casas de taipa; era um matagal, o pessoal foi chegando e fazendo as casas, a luz era à base de óleo diesel, foi através da mina, era o canto mais perto... Aí depois da casa de taipa foi melhorando, foi fazendo, hoje em dia, é só casa tudo alinhadinha, através da mina, não só esse bairro, mas outros como Promorar, IPE, cresceram através dos funcionários de lá. (Joaquim Ramos Pereira, 40 anos - entrevista no bar de Francisco Januário, no bairro Silvio Bezerra em set/13) 


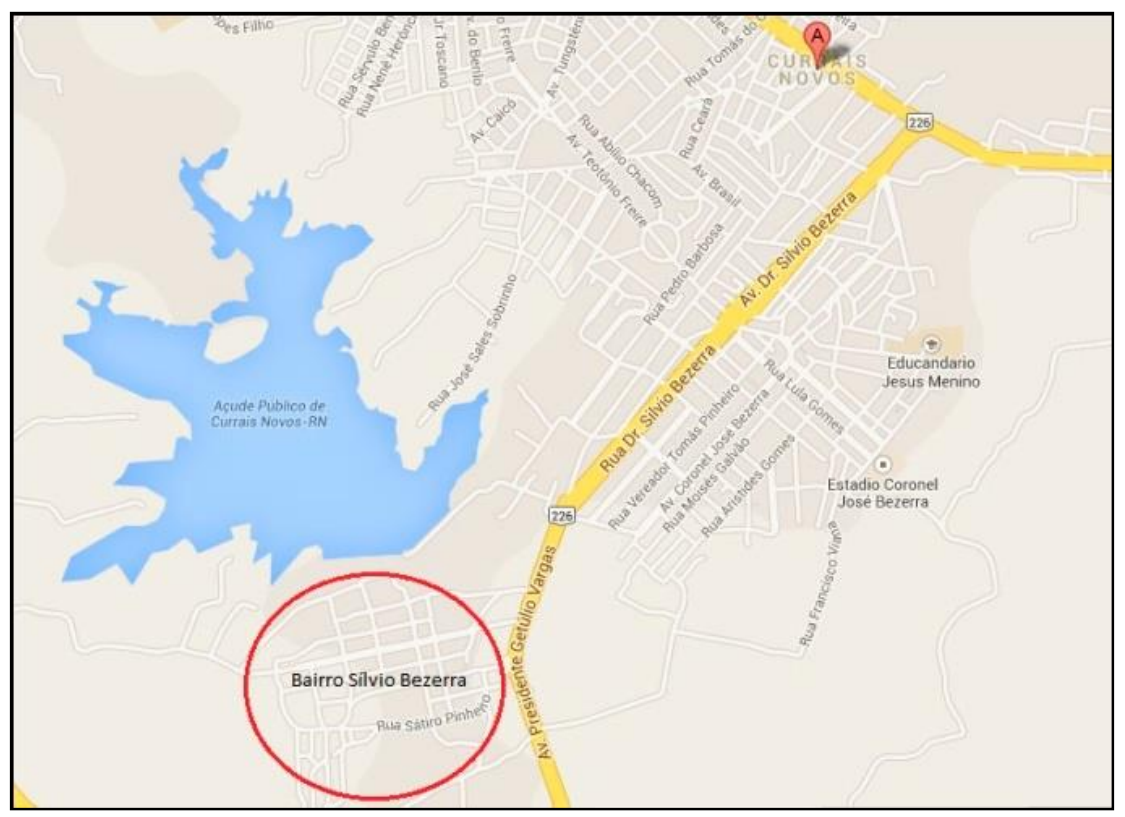

Figura 18: Bairro Sílvio Bezerra em destaque. Fonte: Google Mapas

Assim, o que era em princípio uma simples expressão geográfica, como argumenta Park (1987: 30), converte-se em vizinhança, isso é, uma localidade com sentimentos, tradição e uma história própria, onde a continuidade dos processos históricos é de alguma forma mantida, e o passado se impõe ao presente. Deste modo, o fato de tantos mineiros morarem no mesmo local estimula a convivência entre eles e ajuda a reforçar os laços de companheirismo e solidariedade, afinal, praticamente todos os vizinhos se conhecem de uma forma ou de outra: ou porque já eram colegas de trabalho antes de se tornarem vizinhos ou vice-versa. Como apontou Park, a proximidade e contato entre vizinhos são as bases mais simples e elementar forma de associação com que lidamos na organização da vida cotidiana na cidade.

O bairro conta com cerca de três mil habitantes, é composto basicamente de casas de alvenaria, muitas construídas pelos próprios moradores e dispõe de pequenos comércios, como mercearias e bares. As ruas principais são calçadas, diferentes das transversais, que ainda são de terra. Apesar de afastado do centro da cidade, é urbanizado, conta com serviços de luz e água encanada. Afora a convivência diária no ambiente da mina, nos finais de semana os vizinhos costumam se reunir nos bares como o de Francisco Januário para beber e conversar, quase sempre sobre trabalho. É o trabalho que segue ritmando a vida também fora dos domínios físicos da mina, uma vez que está fortemente ligado à dinâmica do bairro Silvio Bezerra, cujos moradores têm o 
ofício em comum, por isso seguem praticamente a mesma rotina e experimentam iguais angústias, preocupações ou satisfações.

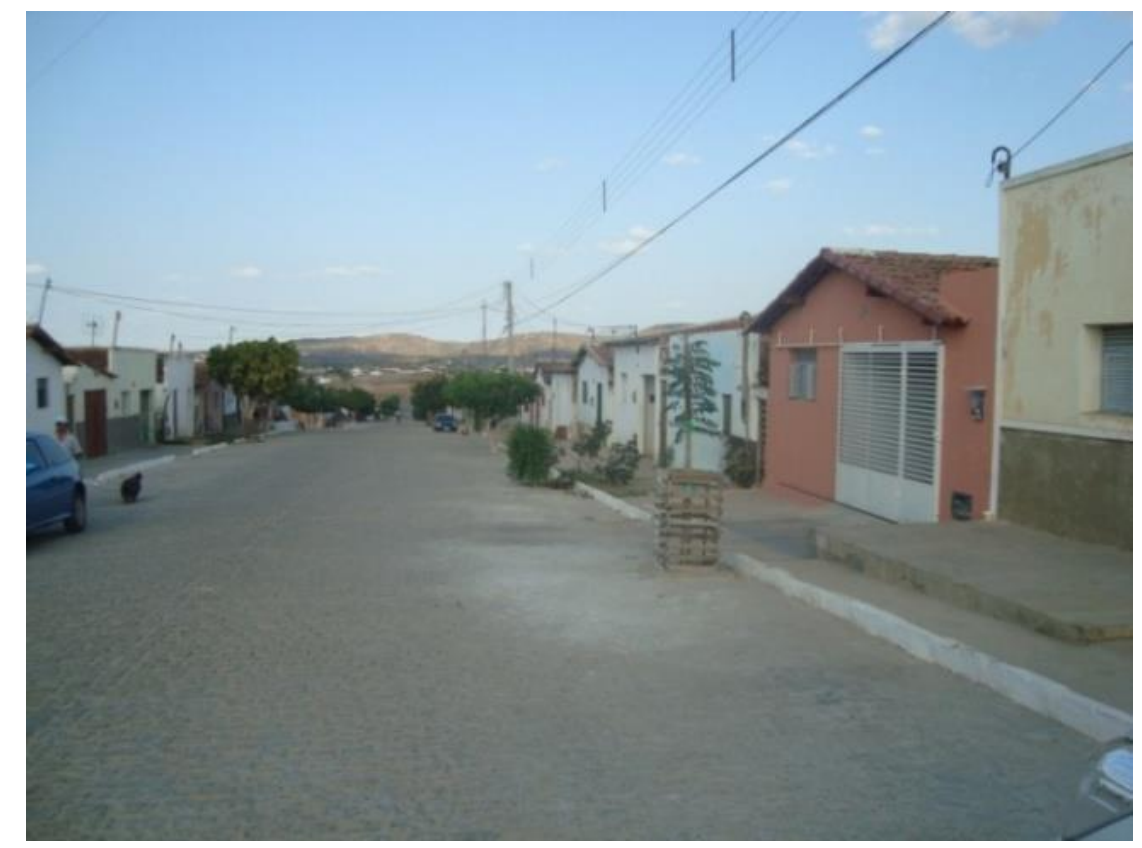

Figura 19: Rua principal do Bairro Sílvio Bezerra. Fonte: Arquivo pessoal da autora

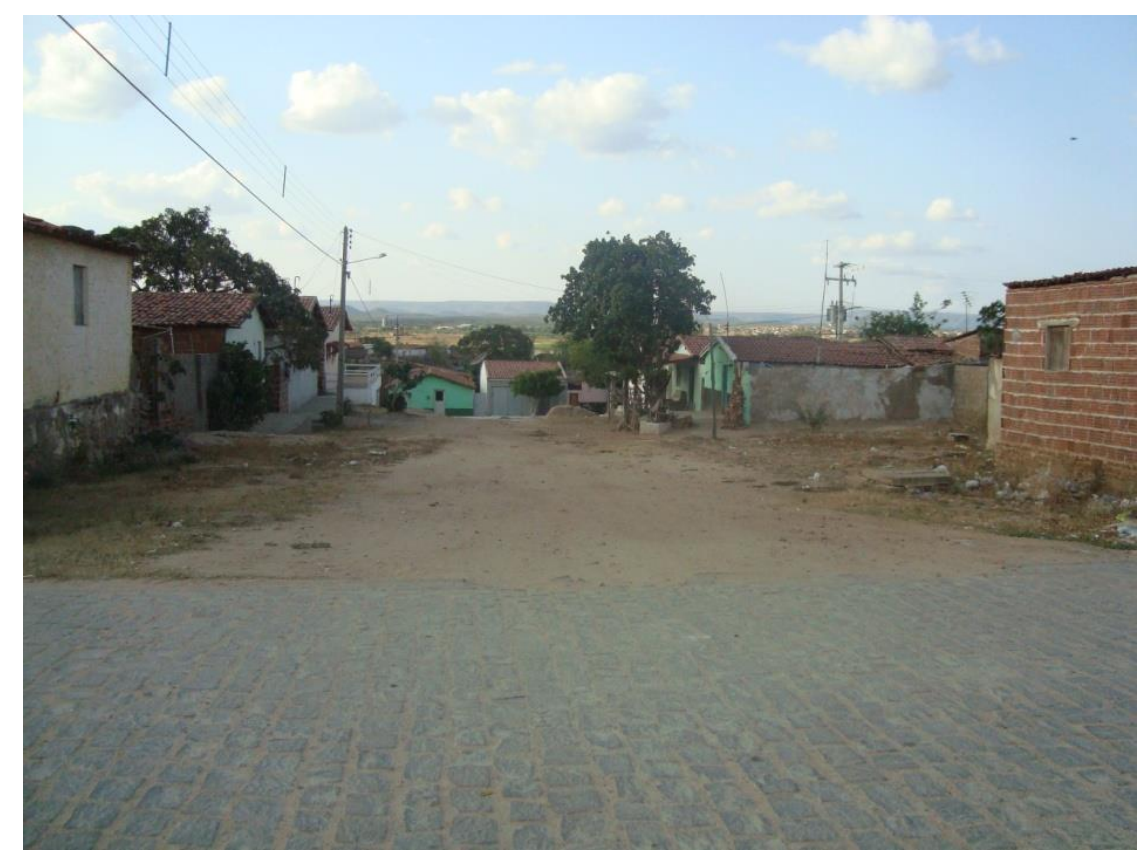

Figura 20: Rua transversal do Bairro Sílvio Bezerra. Fonte: Arquivo pessoal da autora

A rotina de trabalho compartilhada por todos ali inclui o trajeto de casa para o trabalho, e do trabalho para casa, o que é facilitado justamente por todos morarem no 
mesmo lugar: "Os ônibus vêm pegar a gente aqui e vai deixar lá nas minas. No meu tempo ia lá pra beira da pista, ia pegar lá na beira da pista. E agora não, vem pegar na porta de casa. Melhorou muito.” A comparação é feita por Francisco Januário, um dos primeiros moradores do bairro. Ele relembra que chegou ao local por volta de 1980 e, como "morava de aluguel”, foi construindo a casa, na época de taipa, aos poucos. Hoje não só a casa dele é de alvenaria como também as dos filhos, que ficam próximas: "Construi aquela, essa aqui e tem aquela também que é do meu filho. Arrumei tudo através do meu trabalho lá."

A convivência entre vizinhos resulta também na construção e fortalecimento de uma rede $^{6}$ de conhecimentos que facilita o preenchimento de vagas de trabalho, na medida em que um operário indica conhecidos que moram no mesmo bairro para ocupálas. Assim, os mineiros, ao se valerem de sua rede social (Barnes, 1987: 161) através dos laços de parentesco e de amizade para tal, têm fortalecidos os vínculos não só entre os vizinhos, seus pares, reforçando a noção de igualdade de classe ao incluí-los no mesmo ofício, como também atendem à necessidade do patrão ao levar para os quadros da empresa alguém de sua confiança, por quem se tornará responsável no ambiente de trabalho, como acontece entre os operários mais experientes e os mais novos.

A memória do patrão dos mais velhos que trabalharam na Mina Brejuí está presente através do nome do bairro: Sílvio Bezerra, filho de Tomas Salustino e pai do atual diretor da mina, Reno Bezerra. Pergunto aos meus interlocutores se eles sabem o motivo do bairro, que conta com tantos mineiros como moradores, ter recebido esse nome. "Devem ter sido eles mesmos, a família é toda daqui", justifica Francisco Januário. "Ele era um grande homem na cidade, filho do desembargador, ai botaram nesse bairro o nome dele”, argumenta Joca da Barra Verde. Algumas ruas do bairro também levam nomes de parentes dos Salustino, como Jorge Vieira e Manoel Targino, afinal, justifica Januário, "naquela época quem tinha nome era homenageado de alguma forma, né?" Como aponta Le Goff, estamos diante de um constructo social, produzido segundo as relações de forças que detinham o poder, e não de algo que fica, naturalmente, por conta do passado (Le Goff, 2003: 536). Ou seja, ao bairro fundado pelos mineradores, coube o nome do patrão.

\footnotetext{
${ }^{6}$ Sigo o conceito de "rede" utilizado por Barnes, para quem o termo define um conjunto de relações interpessoais concretas que vinculam indivíduos a outros indivíduos (Barnes, 1987: 167).
} 
De todo modo, este é um detalhe que parece não importar para aqueles homens, para quem o que vale mesmo é a tranquilidade de ter a morada garantida. E essa garantia da casa própria veio para os mineiros com a aposentadoria, como é o caso de Joca da Barra Verde e Zé Camada, também residentes do bairro. Morador da fazenda de Tomas Salustino, Joca ainda passou dois anos trabalhando na fazenda depois de se aposentar, para juntar o dinheiro necessário e comprar uma casa no bairro.

Vendi uma vaquinha, umas ovelhas, interei o dinheiro da mineração, comprei essa casinha e vim m'embora pra cá. Era o único canto que podia morar, tudo aqui era mais barato, no centro da cidade eu não tinha condições de morar que uma casa era muito cara e aqui a casa era bem mais barata, tava iniciando. A casinha era pequena na época, depois foi que eu reformei, meu dinheiro só dava pra morar aqui mesmo. No início não tinha quase ninguém porque tava começando, era pouquinhas casas aqui. Isso aqui era quase uma fazenda, aí o dono loteou os terrenos, venderam e a gente foi comprando, foi fazendo, foi fazendo, hoje tá desse jeito. (Joca da Barra Verde - entrevista na casa dele, no bairro Sílvio Bezerra, em out/13)

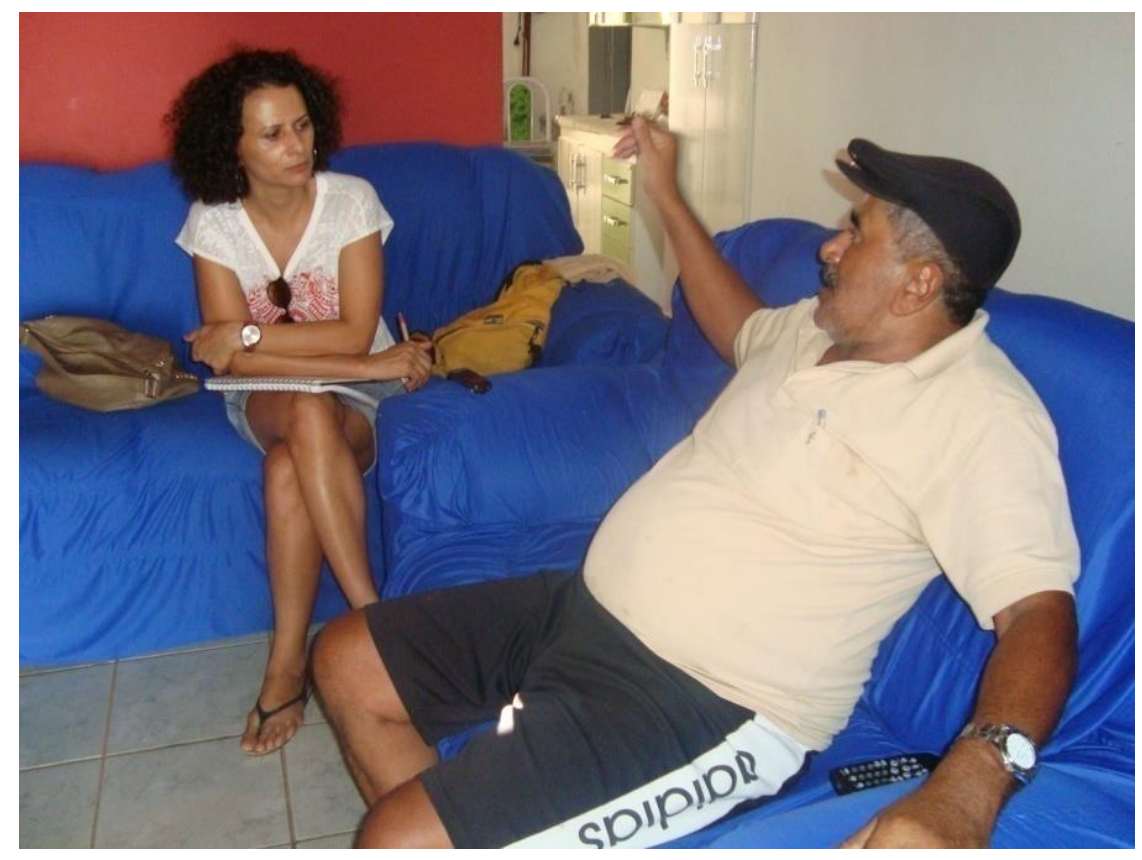

Figura 21: Joca da Barra Verde em sua casa, no Bairro Sílvio Bezerra. Fonte: Arquivo pessoal da autora

Para Joca, que hoje se diz com a vida tranquila, "comecei cedo e soube fazer", trabalhar na mina foi fundamental para poder contar com a possibilidade de comprar uma casa, se aposentar. "Eu vejo tanta gente, tanta gente hoje, amigo meu que não teve chance de trabalhar lá e se trabalhou não sustentou o que arranjou, hoje vive pagando aluguel, vive cheio de necessidade." O alívio de ter uma casa e contar com o benefício da aposentadoria é compartilhado pelo colega Zé Camada, 70, que relembra, muitos 
colegas não quiseram na época, comprar casa no bairro Silvio Bezerra. "Os mais orgulhosos não quiseram e hoje não têm uma casa pra morar, mas o cantinho pra gente era esse. Eu mesmo construí essa casa em cima de uma pedra."

O sentimento de pertencimento ao bairro - um local em que antes da chegada deles "não tinha nada", que começou com casas de taipa, onde a maioria dos moradores é de mineiros - é compartilhado por todos. Eles dividem a participação na construção do local não só física, quanto identitariamente e, talvez por isso, tenham ainda mais reforçado o valor de fazer parte do local. Um local de moradia onde, para que fosse possível chegar, seria necessário o sacrifício de passar 15 anos, em alguns casos até mais tempo, trabalhando no subsolo, e juntar todas as economias acumuladas ao longo deste período, para poder comprar a tão sonhada casa: a realização material, a compensação do ser minerador.

A presença dos mineiros de Brejuí e suas famílias, porém, ao que parece, se limita, atualmente, aos espaços de residência (bairro e vila) e de trabalho. Eles, que antes eram apontados na cidade como pertencentes ao privilegiado grupo de operários da mina, hoje, passam despercebidos aos olhos da população: já não usam os mesmos uniformes azuis que os diferenciavam, nem os capacetes, símbolos de sua identidade como mineradores. A cidade vive das lembranças de um tempo em que a economia girava em torno dos salários dos funcionários das minas. Em nome dessas lembranças, ergueu monumentos que fazem alusão a essa época, como forma de retomar as referências desta identidade e reclamar seu pertencimento. E tal pertencimento não é de agora, vem de bem antes, do início, quando eles começaram na atividade e se viram diante dos símbolos que passariam a representar sua nova identidade de mineradores: as ferramentas de trabalho, o uniforme, o capacete.

\section{$O$ capacete, a identidade}

Apesar do sentimento de otimismo diante das possibilidades que podem se abrir com mais incremento na retomada da exploração da scheelita, os interlocutores seguem cadenciados pelas lembranças de quando a cidade vivia em função da atividade. Eles relembram de um tempo em que trabalhar na mina significava status, prestígio. Ser funcionário da Mina Brejuí se tornaria projeto de vida dos homens não só de Currais Novos, mas também dos municípios vizinhos, para quem só restava a agricultura como 
alternativa. Assim como ocorreu entre os operários de La Grand-Combe, para os operários de Brejuí, o trabalho mineiro também orientaria as qualidades simbólicas de uma "identidade-valor" (Eckert, 2012: 24).

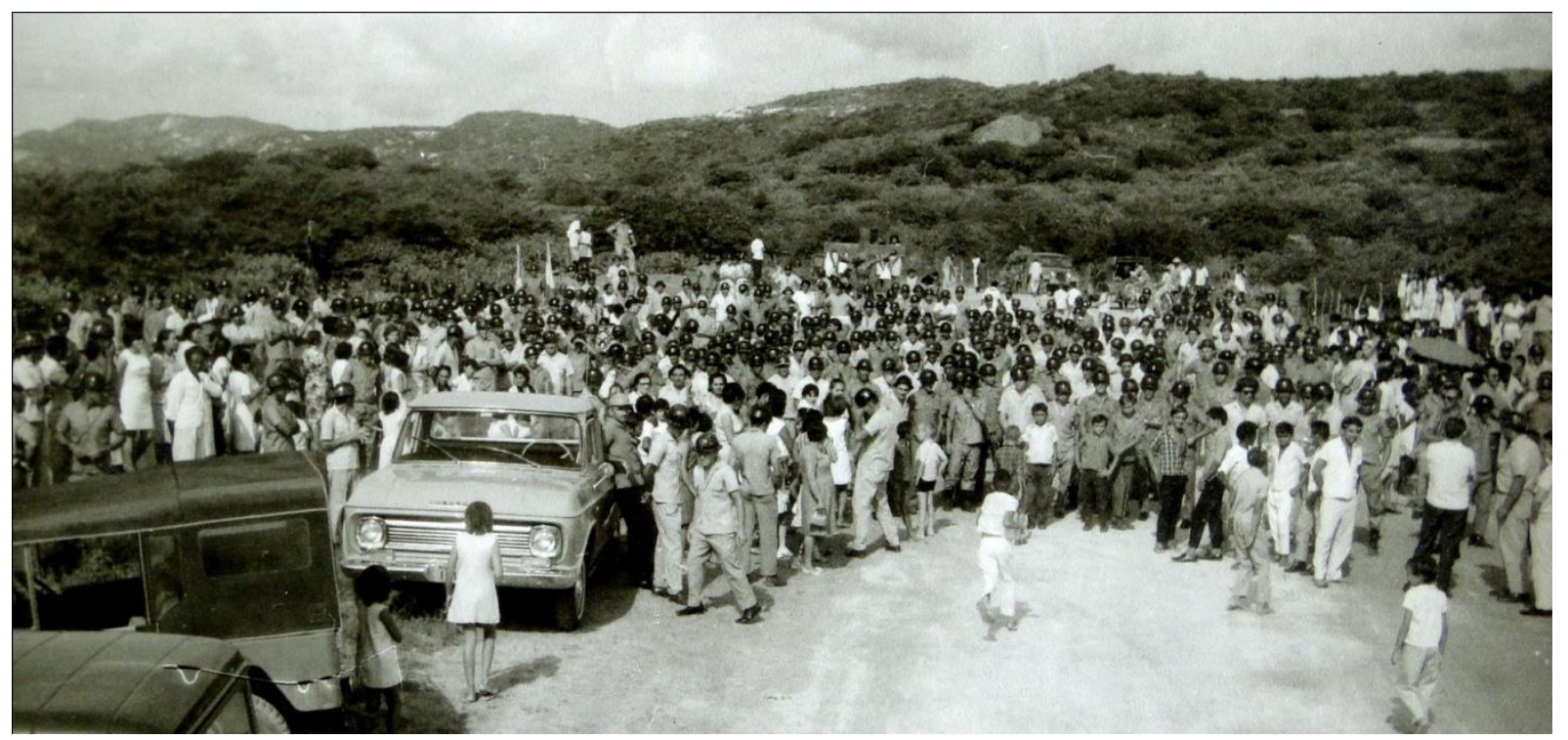

Figura 22: Concentração de operários durante evento na empresa. Fonte: Arquivo da Mina Brejuí

Componentes desta "identidade-valor" entre os mineradores de Brejuí, o uniforme e, especialmente o capacete, aparecem nas falas dos interlocutores como símbolos que reforçavam os valores que diziam respeito à sua identidade como operários. Na figura 22, o brilho dos capacetes se destaca durante evento na Mina Brejuí. Durkheim (2003) já dizia que sem símbolos, os sentimentos teriam apenas uma existência precária. Assim, os mineradores usavam seus uniformes e capacetes também fora do trabalho, como forma de dizer quem eles eram fora do expediente que cumpriam na mina, através daqueles elementos.

Para os comerciantes, estimulados com o aquecimento dos negócios graças ao dinheiro que circulava na cidade, os operários da mina eram tão valiosos quanto a scheelita, por serem os principais responsáveis por movimentar as vendas. "Quando a gente chegava numa loja dessas em Currais Novos, que dizia que era funcionário da mina, vixe Maria, até cafezinho tinha... (ri) Era uma mina que era uma mina! Todo mundo trabalhava, todo mundo tinha condição" (Altamiro Cassimiro da Silva, 50 anos). Carregar o capacete pela cidade, portanto, indicava que aquele indivíduo tinha emprego com carteira assinada, recebia o salário em dia e, consequentemente, dispunha de crédito no comércio. 
Os cabras chegavam com bota e capacete, iam pro Banco do Brasil assim pra ser bem recebido e o povo respeitava, pra eles era um prazer, tinha deles que passava o capacete na bucha chega ficava alumiando... (ri)

Bastava dizer que trabalhava na Mina Brejuí, as portas estavam abertas, todo mundo confiava em operário da Mina Brejuí, teve cabra que ia até pra missa de capacete, de bota, aquelas pessoas mais de idade, eu era mocinho não ia andar de capacete (ri). Eles adorava, gostava daquele troço, achava que tava fazendo uma presença, né. De capacete e bota. O povo tinha orgulho de trabalhar na mina, ainda hoje tem, tem cabra que trabalha lá que é orgulhoso, é.

(Joca da Barra Verde - entrevista na casa dele, no bairro Sílvio Bezerra em Currais Novos em out/13)

Para Cornélia Eckert (2012), a apreensão e a interpretação que os sujeitos fazem da realidade vivida é não só a abstração ou classificação de uma ordem simbólica do mundo, mas também a construção de uma inserção social onde se devem deter os diferentes níveis de interação cultural no seio da sociedade dominante. Neste sentido, o capacete e o uniforme usados fora do horário do trabalho, para aqueles homens, eram uma forma de se sentirem inseridos, participantes e valorizados pela sociedade. Assim, o capacete, cuja utilidade quando usados dentro dos túneis da mina era proteger contra os acidentes de trabalho, sinalizava outro valor pelas ruas da cidade: assumia o símbolo de status, de estabilidade financeira. Uma vez relacionados a outros "eventos", os símbolos estão essencialmente, envolvidos com o processo social, como aponta Turner:

O símbolo vem associar-se com os interesses, propósitos, fins e meios humanos, quer sejam estes explicitamente formulados, quer tenham de ser inferidos a partir do comportamento observado. A estrutura e as propriedades de um símbolo são as de uma entidade dinâmica, ao menos dentro do seu contexto de ação apropriado (Turner, 2005: $50)$.

Os sinais deste pertencimento à identidade mineira, o capacete e o uniforme azul, também identificam os mineiros como os heróis que se arriscam diariamente em busca das riquezas escondidas nas rochas, devido ao alto risco do ofício. Um capacete também esteve presente no relato de Gentil Cortêz: era a lembrança de um colega operário, morto em um acidente na mina. Ele o mantém guardado no almoxarifado como um troféu, uma prova de bravura. "Ele era muito meu amigo e quando ele se acidentou, os colegas do subsolo trouxeram o capacete pra mim e eu guardo aqui até hoje”.

O trabalho na mina, especialmente no subsolo, por mais que conte com estrutura e equipamentos de segurança, é uma atividade de alto risco que exige coragem para descer aos túneis diariamente e passar horas seguidas naquele local escuro e quente, 
esforço físico e solidariedade para enfrentar os momentos difíceis. Elementos reais e imaginários contribuem para a construção de uma imagem mitificada em torno dos trabalhadores mineiros - os personagens que protagonizam esses episódios (Eckert, 1993).

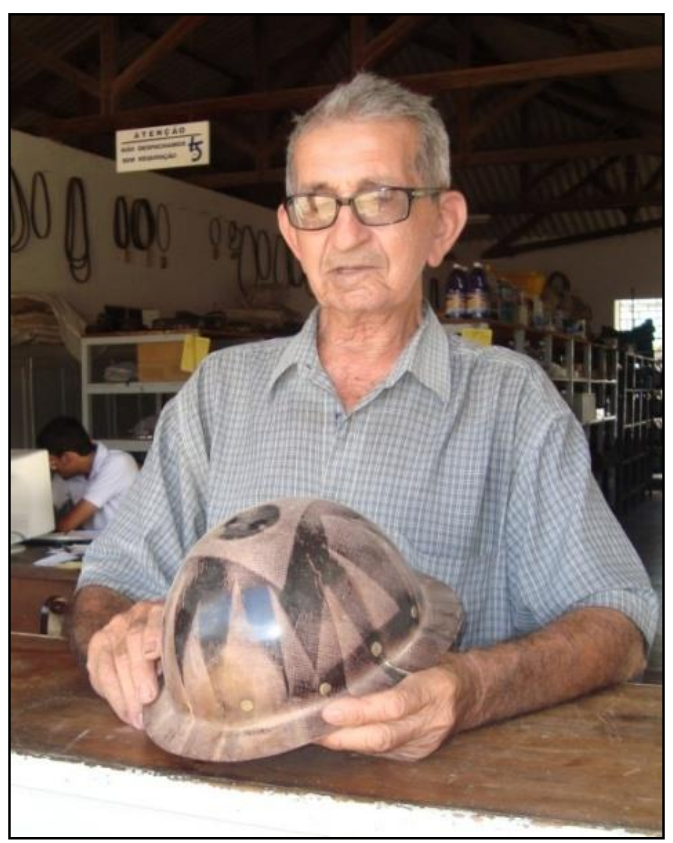

Figura 23: Gentil Cortez com capacete do colega morto em acidente. Fonte: Arquivo pessoal da autora

Ocorre, entretanto, que aqueles trabalhadores, por estarem tão ocupados em garantir o sustento da família, geralmente numerosa, se ocupavam muito mais com o desafio de levar o pão para a mesa, do que se nutrir dos estereótipos construídos em torno deles: corajosos e amantes do seu trabalho. Mesmo que tenham, eventualmente, aceitado o papel de heróis atribuído a eles pela empresa - consequentemente absorvido também pela comunidade - e, ao vestirem o macacão para irem trabalhar, tenham se sentido, por instantes, super-homens, iriam enfrentar os túneis escuros e quentes, iriam explodir rochas e extrair o minério do tactito durante oito horas seguidas diariamente, por pelo menos 15 anos, até completarem o tempo para a aposentadoria, e depois, somariam mais alguns anos seguindo com o ofício, como forma de reforçar a renda. $\mathrm{Ou}$ seja, a batalha deles se restringia à esfera micro - como a preocupação com o sustento da família; o universo macro - o destino que seria dado ao minério retirado por eles, a exemplo dos trabalhadores identificados no documentário “A Pedra da Riqueza” (1976), não parecia importar: 
A scheelita pra mim era o mesmo que desperdício, não sabia pra que servia, depois me disseram pra que é. Hoje sei pra que serve, não fazia diferença porque não era meu. Só fazia minha parte: tirar, ensacar e dar aos donos, pra mim não valia nada, como não vale. Trabalhei 20 anos e nunca tive coragem de trazer uma grama, pra não ser preso, como outros que roubaram.

(Joca da Barra Verde - entrevista na casa dele, no bairro Sílvio Bezerra em Currais Novos - out/03)

Dizia que era pra negócio de explosivo, pra fazer armamento, eles diziam isso né. Mas agora eles não vendem mais assim, é tudo pro exterior, toda semana, toda semana a Brejuí [trecho inaudível]. A scheelita é bem alvinha, ela brilha.

(Zé Camada - entrevista na casa dele, no bairro Sílvio Bezerra em Currais Novos out/03)

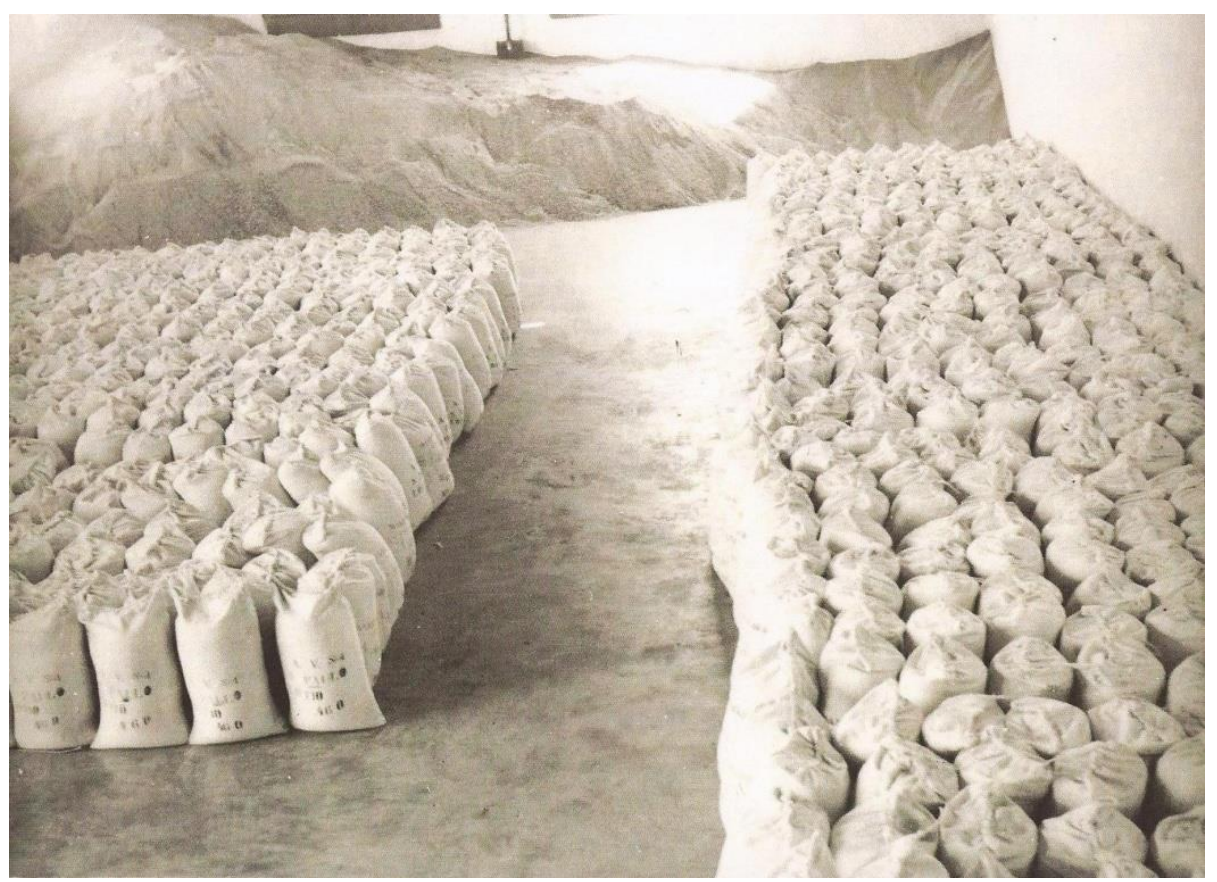

Figura 24: Sacos de scheelita de $50 \mathrm{~kg}$ beneficiada prontos para a venda. Fonte: Arquivo da Mina Brejuí

De fato, conhecer o destino do minério e o desenrolar da cadeia produtiva da qual faziam parte, não tinha importância para eles. Importava apenas saber que ao final do mês receberiam seus salários com o qual pagariam as contas e seguiriam cuidando do sustento de suas famílias com o suor do seu trabalho. E, como forma de compensação, receberiam, de vez em quando, os cumprimentos e desfrutariam o bom atendimento no comércio ao saírem pelas ruas exibindo seus capacetes e uniformes. Os símbolos de uma identidade mineira ostentados com orgulho por onde passavam, justamente por representarem tudo o que eram: heróis, operários, trabalhadores, homens corajosos, pais de família, mineradores. Isso parecia ser suficiente, tanto, que o processo de 
conscientização de classe demorou décadas para acontecer: só se concretizou ao ser realizada a primeira e única greve.

\section{A consciência de classe e a greve}

Em seu estudo sobre a formação da classe operária na Inglaterra, Thompson aponta que um dos fatores que estão atrelados à formação da classe operária é o crescimento da consciência de classe: a consciência de uma identidade de interesses entre os diversos grupos de trabalhadores contra os interesses de outras classes (Thompson, 2004, Vol. II: 17). No caso de Brejuí, os relatos demonstram que esse compartilhamento de interesses comuns que poderiam gerar a consciência de classe entre os operários demorou a aparecer, uma vez que eles mantiveram no ambiente de trabalho fabril a mesma postura de quando eram colonos nas terras do patrão fazendeiro.

"Os trabalhadores naquele tempo era tudo inocente, não sabia procurar os direitos; o cabra é analfabeto, não conhece os direitos, não sabe nada, é cego. Eu mesmo só estudei até a $4^{a}$ serie. Morando no sitio, trabalhando de dia e de noite, não tinha condição" (Joca da Barra Verde). Pergunto a ele se os operários tinham consciência de classe.

Tinha nada, o pessoal do meu tempo, tinha nada. Depois foi aprendendo alguma coisa, mas naquele tempo corria froxo em todo canto, homem. Tinha nada, ninguém tinha direito a bota, não tinha direito a capacete, nem a farda, eles não iam dar. Aí depois inventaram o sindicato, o Ministério do Trabalho começou a atuar nas firmas aí foi melhorando, como hoje tá melhorando. (Joca da Barra Verde - entrevista na casa dele, no bairro Sílvio Bezerra, em out/13)

O sindicato dos trabalhadores foi criado pela própria empresa, dois anos depois da fundação da Mineração Tomaz Salustino S/A, coordenado pela agência local da Delegacia Regional do Trabalho juntamente com funcionários do escritório da mina (Cunha, 1988: 58), que também compuseram a diretoria. Porém, ao invés de atuar como um instrumento de lutas por melhorias salariais e conquistas de benefícios trabalhistas, tinha a vaga missão de "congregar a classe dos trabalhadores na indústria de mineração em associação profissional", de acordo com sua Ata de Fundação, datada em 1945. Por isso, a instituição era desconhecida pelos operários, que como Joca, só foram tomar conhecimento do sindicato bem depois de sua fundação. 
O objetivo do sindicato, de acordo com o documento, era proporcionar "assistência médico-hospitalar, dentária, farmacêutica e educacional". Todos os funcionários, portanto, desde os engenheiros até os operários, eram compulsoriamente associados ao sindicato no ato da contratação. O papel do Sindicato dos Trabalhadores da Indústria do Ouro, Diamantes, Metais e Pedras Preciosas nascido em Brejuí, caracterizava, a exemplo de outros sindicatos instituídos na época no país, a política trabalhista do Estado Novo, atuando de forma conciliadora em relação aos patrões e prestando serviço assistencialista, da mesma forma como também acontecia nos canaviais pernambucanos (Leite Lopes, 1976: 04).

Assim, o sindicato dos mineradores seguiu prestando seus serviços assistenciais para os quais foi fundado, enquanto os operários mantinham o posicionamento passivo, limitado a receber as ordens do patrão e a cumpri-las, como faziam desde que a mina "fichou" seus funcionários em 1953. O vigor de uma forma de dominação pode ser avaliado por sua interiorização pelo próprio grupo dominado (Leite Lopes, 1988: 32). Essa "harmonia", porém, só seria quebrada em 1986, mais de quatro décadas depois, quando houve a primeira e única greve dos operários das minas de Currais Novos. " $N a$ época, [o sindicato] não era tanto a favor da gente, mas deu uma ajuda, apesar do presidente ser funcionário ${ }^{7}$, mas deu uma força. Naquele tempo corria frouxo tudo" (Joca da Barra Verde). De fato, a desvinculação com as lutas de classes era tanta, que o sindicato só tomou conhecimento da greve ao ser deflagrada, e só se envolveu depois, cumprindo o papel de negociador entre as partes (Cunha, 1988: 58). O contexto nacional dava lugar a movimentos sindicais estimulados por instituições como a CUT Central Única dos Trabalhadores (Giannotti, 2007), que contava com representação no Rio Grande do Norte e deu suporte aos mineradores em suas reivindicações.

Era no tempo que o salário era 13 reais, reais não 13 cruzeiros, era o pessoal meio aperreado, fizeram uma greve da bexiga lá. O que deu? Ficharam outras pessoas, botaram anúncio na rádio que tavam precisando de 100 homens mais ou menos, chegaram 150 e no outro dia botaram os novatos pra ir trabalhar. No final, veio uma tal de CUT e foi obrigado o sindicato botar nós velhos pra trabalhar e botar os novatos pra fora e findaram pagando os novatos e pagando os velhos (ri) foi pior pra eles, né?

\footnotetext{
${ }^{7}$ A ressalva ao fato de o presidente do sindicato ser funcionário, significa que ele não era operário, e sim, integrante do setor administrativo da empresa, o que o torna hierarquicamente superior para os operários.
} 
E vocês conseguiram o que queriam?

Um pouquinho, não foi tanto, mas também não foi tão pouco, conseguiram alguma coisa. (Joca da Barra Verde - entrevista na casa dele no bairro Sílvio Bezerra em Currais Novos em out/13)

$10 \%$ que a firma deu e quis tomar, foram 15 dias parados, nós pequenos temos que se unir, foi $10 \%$ que nós ganhamos. A maioria parou, era mais de mil, passou 15 dias indo pro sindicato tomar café pra ver se ganhava o negócio. (Francisco Januário - entrevista na casa dele no bairro Sílvio Bezerra em Currais Novos, em set/13)

Situação parecida à dos salineiros de Mossoró/RN pesquisados por Brasília Ferreira, cujas primeiras tentativas de reivindicações por melhorias de trabalho não passaram de movimentos isolados. Só em 1932, com o apoio do Partido Comunista que havia contribuído com a organização daqueles trabalhadores, é que o Sindicato dos Operários do Sal conseguiu mobilizar uma "greve geral" envolvendo todas as salinas da região por melhorias salariais e regulamentação das medidas usadas como referência para a produção de sal, além do direito a água limpa para consumo e retorno ao trabalho dos colegas expulsos por reclamarem das condições de trabalho (Ferreira, 2000: 120).

Aquela, entretanto, era outra situação, apesar da semelhança que havia entre os trabalhadores do sal e os da Mina Brejuí, onde eram fortes os laços de amizade e compadrio com os proprietários da terra/patrão, cuja imagem produzida ideologicamente é a do parceiro ou aliado na produção (Ferreira, 2000: 121). Os operários da scheelita não contavam com uma orientação como os operários do sal tiveram do Partido. Eles só tinham a si mesmos e à necessidade em comum de obter reajuste salarial, além de outros benefícios, como relembra Elisbão Bezerra: “reivindicavam salário atrasado, prêmio... Que um diretor que reajustava o prêmio faleceu e os outros não queriam reajustar".

A pressão entre os grevistas era forte contra os que insistiam em trabalhar. Eles montaram piquetes nos portões das minerações para evitar a entrada dos colegas “furões". Elisbão usou o fato de já ser aposentado como argumento para não aderir à greve, pois para ele, era um "favor" que os patrões lhe faziam ao permitir que trabalhasse depois de aposentado. "Favor" foi também o que fez Joca da Barra Verde ao patrão quando, apesar de ter aderido à greve, não pôde negar a um pedido do chefe que foi até a casa dele, no bairro Silvio Bezerra em Currais Novos, para realizar um serviço durante a paralisação. 
Eu sempre fui um cara que gostou de trabalhar, não podia faltar o homem, então eu fui. Quando cheguei lá era muita gente no portão, todo mundo gritou: “os babão, os babão vai trabalhar". Mas deixa que eu não fui trabalhar, fui puxar umas peça que tava precisando, quem puxava era eu, eu fui e voltei. Foi de tarde que eu cheguei ali, eu nem levei o capacete na época porque se eu fosse no traje de ir trabalhar eles ia logo bagunçar né. Mas quando eu cheguei os cabra gritaram: "Joca, tenha vergonha, você é um babão", eu: "homem eu fui puxar umas peça lá, que eu não podia deixar de ir, se me botassem pra fora pra mim ia ser pior, aí eu fui atender o chamado do homem". (Joca da Barra Verde - entrevista na casa dele, no bairro Sílvio Bezerra, em Currais Novos em set/13)

Joca da Barra Verde que se sentia na posição de obediência e respeito ao patrão, o mesmo patrão da fazenda em que foi morador durante toda a vida, junto com sua família. Para ele, seria uma afronta a tudo o que o patrão fez por ele e à sua família dizer "não" ao seu pedido, que, além de contrariá-lo, ainda poderia resultar em sua demissão. Assim, na condição de subalterno, silenciou $^{8}$ e obedeceu.

A greve chamou a atenção da imprensa do Estado, um acontecimento histórico que envolveu trabalhadores das outras minas vizinhas (cerca de 1.800 operários pararam, segundo os jornais da época) e deixou os patrões irritados, como mostra a reportagem do Diário de Natal ao destacar o depoimento do diretor da Mina Brejuí à época, Mário Moacir Porto:

Ressaltando que a empresa teve que vender seu patrimônio imobiliário para mantêla, Mário Moacir Porto desabafou: o que irrita nisso tudo é que o próprio operário sabe que o preço da scheelita é o mais baixo dos últimos 20 anos. Ponderou que a remuneração dos operários da empresa é satisfatória, uma vez que o menor salário é de $\mathrm{Cz}$ 1.300,00 pago ao operário sem qualificação profissional.

Mário destacou ainda que os operários que moram na mina têm casa, água e luz de graça. Os que moram em Currais Novos, distante oito quilômetros do local da mina são transportados em ônibus. A mineração está em atividade ininterrupta desde 1943, quando foi fundada e só teve cinco reclamações trabalhistas (DIÁRIO DE NATAL, 09/10/86).

O discurso do patrão aqui, reforçado pelo jornal mais de 30 anos depois da publicação da reportagem de "O Cruzeiro" que tinha Tomaz Salustino como personagem de destaque, parecia permanecer o mesmo daquela época, apesar da mudança do contexto: seus trabalhadores eram privilegiados, não tinham motivos para queixas, afinal, dispunham de casa, água, luz, transporte. Que razões havia para reclamar? Moravam numa cidade repleta de abundância, com hospital, hotel, comércio,

\footnotetext{
${ }^{8}$ Utilizo aqui o conceito de subalterno de Spivak, para o qual é negada a fala em um espaço de dominação (Spivack, 2003).
} 
praças, ruas calçadas, tudo graças ao "progresso" trazido com a Mina, que gerou seus empregos e trouxe riqueza para todos.

Aquele momento, no entanto, para os operários, era a oportunidade de se posicionar como trabalhadores que reclamavam os direitos negados pelos patrões. Foi também ali que eles demonstraram se perceber como classe e, com o protesto, tomariam consciência sobre si: iriam além das "cinco reclamações trabalhistas" desde a fundação da mina: contavam agora com uma greve geral de 15 dias para dar corpo à sua consciência de classe. Foi preciso haver o conflito trazido com a paralisação para que viesse à tona a negação, por parte dos operários, da "unidade" operada pela empresa. Como aponta Simmel, o conflito é um fato sui generis e sua inclusão sob o conceito de unidade teria sido tão arbitrária quanto inútil, uma vez que o conflito significa a negação da unidade (Simmel, 1983: 123).

Assim, a fronteira da subordinação - tomando como referência Guilherme Velho em sua obra Capitalismo, Autoritarismo e Campesinato - se ampliou para os operários de Brejuí, a exemplo do que Velho apontou quando as fronteiras se abrem para o campesinato: aumentam-se as possibilidades de uma trajetória social ascendente e o enfraquecimento de uma subordinação estrita e imediata (Velho, 1976: 101). Mesmo que o reajuste conquistado com a greve tenha sido abaixo do que esperavam, os operários não escondem a sensação de vitória com o empreendimento, que lhes traria mais autoconfiança e a certeza de terem uma voz que poderia ser ouvida.

Não houve, no entanto, outra paralisação igual àquela depois. Naquela ocasião a Mina Brejuí enfrentava uma de suas mais graves baixas de produção, que culminaria no encerramento de suas atividades oito anos depois. Para os operários, no entanto, a greve foi um marco divisório entre o perfil de um operariado passivo que se limitava a cumprir de cabeça baixa as ordens do patrão - herança dos tempos do roçado - e o operariado que descobria seu poder de reivindicação. Eles tomariam para si a consciência de que formavam uma classe, que unida, detinha a capacidade de mudar o cenário em seu favor.

O impacto do fechamento das minas, no entanto, dissipou seus integrantes, que foram buscar trabalho em outros estados. O que ficou entre os que permaneceram foi a satisfação da conquista e as lembranças de um tempo em que se descobriram enquanto classe. Para a empresa, depois do fechamento de suas portas, restaram as memórias - 
representadas através de túneis abandonados, equipamentos parados, fotos, objetos pessoais do seu fundador - e a pergunta: o que fazer com elas?

\section{O memorial, o museu - as lembranças que restaram}

Depois que se viu com a produção da empresa paralisada e de portas fechadas, sem mais o ir e vir dos operários na saída e entrada dos turnos de trabalho, restou à família Salustino, buscar o que havia para guardar e preservar (Canclini, 1997: 96) a respeito do patriarca que tanta influência teve sobre o modo como os negócios seguiram sendo conduzidos pelos sucessores. Assim, a direção da mina resolveu criar em 2006, o Memorial Tomaz Salustino e o Museu Mineral Mário Moacyr Porto, ambos instalados no prédio onde antes funcionava o escritório da empresa. Foi a maneira encontrada para manter "lembrada" a trajetória familiar e profissional do fundador da Mina Brejuí.

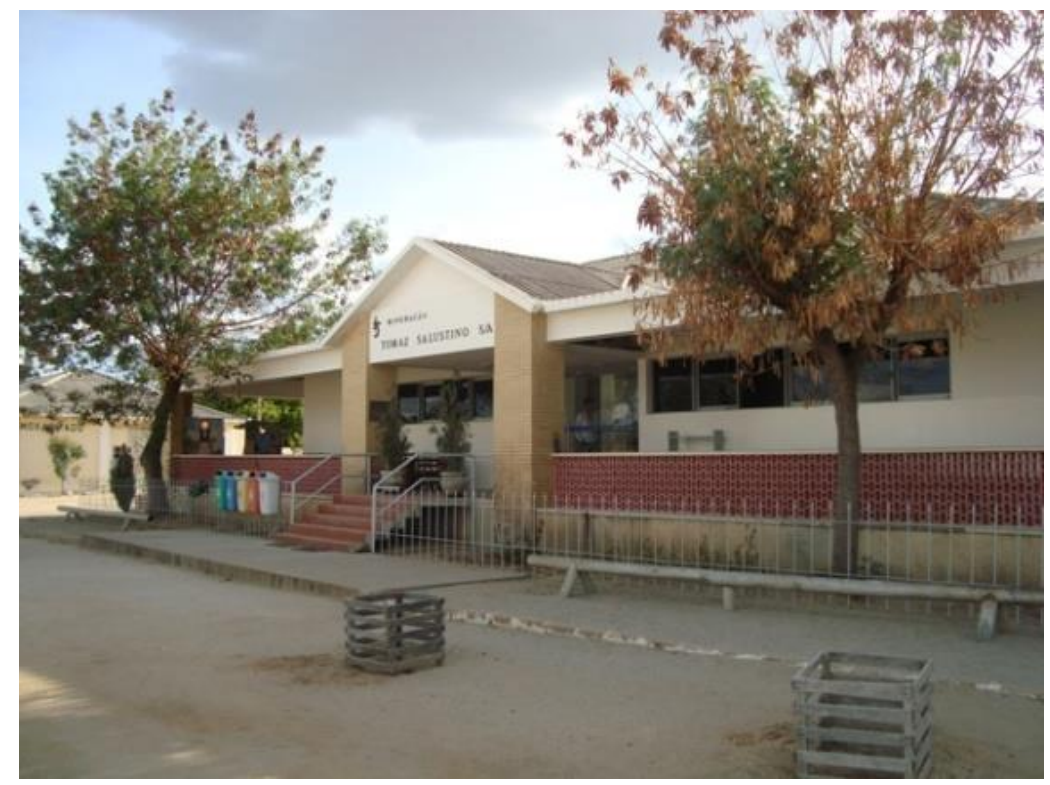

Figura 25: Memorial Tomaz Salustino e Museu Mineral Mario Moacyr Porto. Fonte: arquivo pessoal da autora

A primeira parte do prédio foi dedicada à exposição de objetos pessoais de Tomaz Salustino, como a cama em que dormia, a toga que usava como desembargador, livros e discos preferidos, além de muitas fotos, que registram, entre outros momentos, as diversas fases da mina, além dos encontros históricos entre ele e empresários e políticos nacionais e internacionais. Como Candau aponta, todo indivíduo morto pode converterse em objeto de memória e de identidade, tanto mais quando estiver distante no tempo 
(Candau, 2011: 143). Na segunda parte do espaço está instalado o Museu Mineral que recebeu o nome de um dos filhos de Tomaz Salustino, Mário Moacyr Porto, onde é possível conhecer as diversas cores e formas em que a scheelita se apresenta, além de vários tipos de minérios encontrados na área da mina e na região.

Originados, portanto, para dar sentido ao tempo de paralisação da empresa, o museu e, especialmente, o memorial surgiram também para produzir sentido à passagem do tempo, além de cumprir o papel de fixar e reativar a memória - produtora de identidade (Pollak, 1989) - em torno de um indivíduo: Tomaz Salustino. A proposta desses espaços de memória, assim, reforça a noção de identidade que o objeto patrimonial pressupõe, que é reproduzir a história da empresa e produzir narrativas sobre o passado do seu fundador. Isso justifica o fato de o patrimônio ser uma forma de escrita do passado que varia de acordo com as contingências temporais e sociais (Gonçalves, 2012). Os conteúdos e objetivos dependem de quem parte a iniciativa de como será organizado o "colecionamento" - processo de formação do patrimônio e a composição da coleção de objetos móveis e imóveis que será exposta, afinal, o patrimônio não é só usado para simbolizar, representar ou comunicar. É também utilizado para agir. Afinal, essa categoria faz a mediação entre seres humanos e divindades, entre vivos e mortos, entre passado e presente (Gonçalves, 2012).

Numerosos museus locais são resultado, como aponta Candau, de uma tentativa de "criação" de uma identidade coletiva regional pela encenação do passado no presente. Esses museus, segundo ele, concorrem para redefinir localmente as "escolas identitárias" pertinentes (Candau, 2011: 161). Foi o que aconteceu, por exemplo, em La Grand Combe, onde restou aos mineiros, habituados a transmitir os conhecimentos e práticas de trabalho, assistir à criação do Museu do Carvão e Salão Cultural do Carvão, onde foram expostos as técnicas e o conhecimento do trabalho deles, transformado daquela forma, em patrimônio cultural (Eckert, 2012: 67).

Não foi o que aconteceu, no entanto, no caso do museu mineral e do memorial de Brejuí. Lá, com exceção de uma bateia que está exposta, nada mais faz referência ao trabalho dos mineradores. Há, porém, no local, uma homenagem a Seu Gentil: foi afixada uma placa onde está escrito: "Uma homenagem a José Gentil Cortêz, funcionário mais antigo, a pedra mais preciosa da Mina Brejuí". Apesar de se dizer orgulhoso com o reconhecimento, Seu Gentil confessa que preferia que a homenagem tivesse acontecido através de uma forma mais concreta, como um "aumento no salário". 
Eles botaram lá dentro (do museu) uma coisa sem eu querer, uma homenagem, só propaganda e mais nada. Uma pessoa que começou a mina... Eu digo: "Dr. Carlos, eu quero ir embora". Ele disse: "não, eu vou botar uma homenagem pra você lá dentro, e você vai ficar como uma pedra preciosa". Eu disse: "é propaganda". Quer dizer, de qualquer maneira, eu preciso é do emprego, né. Se eu não tivesse empregado aqui, de qualquer maneira, tá me ajudando, né. Quem é que quer uma pessoa idosa como eu pra trabaiá? Quem é que quer me dar um emprego? Ninguém!

Os diretor aí diz que eu sou uma pedra que não se acaba aqui na mina, né. Porque de 1953 pra cá, tudo o que tem aqui dentro da mina eu sou sabedor, aonde é que tá ou se venderam ou se num venderam, ou onde tá. Sempre eles quando precisa de uma coisa assim que não acha, eles vem logo a mim e eu acho! Meu trabalho é esse, de uma vez que meu trabalho é esse, de uma vez que eles precisa e num sabe, eu tou aqui pra dizer onde é que tá. (Gentil Cortez, 82 anos - entrevista no almoxarifado da mina em set/out/12)

Seu Gentil, a "pedra mais preciosa" da Mina Brejuí é também seu maior detentor dos saberes que dizem respeito ao almoxarifado, além da memória que guarda sobre o início da empresa, uma vez que trabalhou com o pai quando ainda garimpo, quando criança aos 11 anos. Da mesma forma que guarda cada peça que não é mais usada pela empresa, ele guarda igualmente as memórias do trabalho. Tudo o que diz respeito àquele espaço onde passa o dia inteiro arrumando, limpando, consertando, ele é sabedor. O almoxarifado fica localizado ao lado no memorial, há poucos metros do local em que está a homenagem a ele, onde nunca vai. Entretanto, no dia em que fazia a entrevista com ele, perguntei se podíamos ir até lá para que mostrasse a tal homenagem.

Ele concordou e nos levou até o prédio vizinho. Chegando lá, todos tiramos os sapatos (não pode entrar calçado) e fomos seguindo Seu Gentil enquanto ele mostrava as fotos e objetos pessoais do patrão, os minérios expostos, a bateia, explicando o que era e para que servia. Antes, porém de chegarmos até o local da homenagem, fomos surpreendidos pela secretária da administração da mina que foi até lá nos avisar que não estávamos autorizados a filmar nem fotografar dentro daquele espaço. Atendemos à orientação prontamente e saímos. Lá fora, porém, Seu Gentil não escondeu a decepção: "vou pedir pra tirar essa homenagem aí. Se eu não posso entrar com pessoas amigas ou parentes pra tirar uma foto lá, pra que eu quero uma homenagem?". O patrimônio deve ser encarado com algo "vivo", como algo não "embalsamado" (Canclini, 1997: 94), diferente do que sucedeu com a "homenagem" a Seu Gentil com a qual ele não se identifica.

$\mathrm{Na}$ escolha por qual memória preservar, a administração da Mina Brejuí optou pelas memórias do patriarca da família. E, ao decidir prestar uma homenagem ao seu 
funcionário mais antigo, Gentil Cortêz, o fez de acordo com o ponto de vista institucional, que para ele não tem sentido. Entre as referências que dizem respeito ao período do garimpo, por exemplo, apenas uma bateia se faz representar. Lá não estão outras ferramentas de trabalho, nem fotos dos garimpeiros e operários expostas, apesar do acervo que a família e a empresa dispõem a respeito. Neste processo de definir que memórias e tradições se quer preservar, outros sujeitos e memórias certamente ficam de fora, uma vez que se elege um "passado significativo" de acordo com as referências de quem tem o poder de decisão. Para Raymond Willians, neste processo “(...) certos significados e práticas são escolhidos para ênfase e certos outros significados são postos de lado, ou negligenciados. (...) é uma versão do passado que se deve ligar ao presente e ratificá-lo" (Williams, 1979: 119).

Seu Gentil não reclamou para si o título de "pedra mais preciosa", que pelo que conta, surgiu como uma compensação pelo fato de ele querer ir embora da mina. A empresa o teria considerado merecedor de tal homenagem por ele ser o funcionário mais antigo. A homenagem para Seu Gentil, no entanto, mesmo que o envaideça, não passa para ele de uma "propaganda", já que não se vê como "pedra mais preciosa", a exemplo do que Candau verificou sobre o risco de desnaturalização que acompanhou os projetos de conservação da memória dos mineiros do norte da França. Essa memória de lutas e sacrifícios da corporação, segundo ele, se nutre de estereótipos que representam o mineiro como um ser "corajoso, amante de seu trabalho, vinculado à mina e ao bairro operário no qual vive”. Uma memória que participa da construção de uma identidade social e cultural "estatutária" que os torna inaptos a toda adaptação ao presente e ao futuro (Candau, 2011: 191).

Os mineiros do norte da França, de acordo com Candau, sofreram com suas histórias porque aceitaram representar o papel atribuído a eles por outros: deixaram-se reduzir à memória esclerosada por certos mecanismos institucionais e ideológicos: indivíduos para quem bastava trabalhar, manter suas famílias, frequentemente com dificuldades e que, provavelmente, não tinham entre suas principais preocupações, questões identitárias, nem patronais ou memoriais (Candau, 2011: 200). Aos mineiros de Brejuí também não parecia interessar outras preocupações além de cumprir com suas horas de trabalho, para em troca, receber seu salário e, ao final da jornada de 15 anos, ter o direito à aposentadoria e então, poder comprar uma casa e desfrutar o sossego advindo com o benefício. Poderiam ainda optar por continuar trabalhando por mais 
algum tempo como forma de engrossar o caldo do feijão que continuavam levando à mesa diariamente.

Eventualmente se dariam ao prazer de desfilar com seus capacetes e uniformes azuis pelas ruas para, em troca, receberem o reconhecimento ao seu duro e perigoso ofício, em forma de cumprimentos e sorrisos de comerciantes e moradores da cidade. Cidade que conheceria o que é o "progresso" graças às riquezas retiradas do subsolo com o seu trabalho e ao custo de muitas vidas que se contam nos episódios vividos e assistidos pelos colegas. Alguns carregam no corpo as marcas dos riscos que corriam diariamente no exercício do ofício de mineiro. Além das marcas físicas, levam também as lembranças de toda a trajetória que traçaram ao optar pela mina ao invés do roçado, mesmo que tenham mantido os vínculos com a enxada enquanto "telavam" e "bateavam" no garimpo ou enquanto, mais tarde, "caçambavam" e "paleavam" nos túneis.

Assim, diante da vocação de Currais Novos para a exploração mineral, é possível perceber que há uma identidade mineira que nasceu a partir do momento em que os agricultores atenderam ao chamado da bateia para ir trabalhar no garimpo de Brejuí. É nítido, porém, que as referências a esta identidade estão circunscritas aos redutos de concentração dos mineradores: a vila operária, a rua e bairro operários e a própria mina. A cidade vive à sombra das memórias do tempo de abundância, erguendo novos e mantendo antigos monumentos que fazem referência àquela época. Os trabalhadores, no entanto, não vivem apenas das lembranças daqueles tempos: seguem também com a expectativa de que a atividade seja retomada com o mesmo vigor de antes e traga de volta os ares dos bons tempos de "fartura" e "progresso" para as novas gerações de mineradores de Currais Novos.

\section{Referências}

ALTHUSSER, Louis. Lenin and Philosophy and others essays. Trans. Ben Brewester. Monthly Review Press. New York. 1971.

BARNES, J. A. Redes sociais e processos políticos. Em: Feldmann-Bianco. B. (org.) A Antropologia das sociedades contemporâneas. SP: Global, 1987.

BENJAMIN, Walter. Magia e técnica, arte e política: ensaios sobre literatura e história da cultura. Trad. Sérgio Paulo Rouanet. $8^{\mathrm{a}}$ ed. revista. São Paulo: Brasiliense, 2012. 
CANCLINI, Néstor García. Imaginários Urbanos. Buenos Aires: Ed. Universitária de Buenos Aires, 1997.

CANDAU, Jöel. Memória e Identidade. São Paulo: Contexto, 2011

CUNHA, Maria Vilma da. A mineração em Currais Novos (um estudo do cotidiano operário). Natal/RN: UFRN, 1988.

DAMATTA, Roberto. A casa e a rua: espaço, cidadania, mulher e morte no Brasil. Rio de Janeiro. Rocco, 1984.

DIÁRIO DE NATAL. Brejuí não aceita as reivindicações: greve. 1986.

DURKHEIM, Emile. As formas elementares da vida religiosa. São Paulo: Martins Fontes, 2003.

ECKERT, Cornélia. Memória e Identidade. Estudo Etnográfico dos Ritmos Temporais e da Duração Social de uma Comunidade de Trabalho no Sul da França. Goiânia: Editora UCG, 1993.

Memória e Trabalho: etnografia da duração de uma comunidade de mineiros de carvão (La Grand-Combe, França). Curitiba-PR: Editora Appris. 2012.

FAORO, Raymundo. Os Donos do Poder: Formação do Patronato Brasileiro. Porto Alegre / São Paulo: Editora Globo, 2001.

FERREIRA, Brasília. O Sindicato do Garrancho. Mossoró: Fundação Vingt-Um Rosado, 2000. GIANNOTTI, Vito. História das lutas dos trabalhadores no Brasil. Rio de Janeiro: Mauad X, 2007.

GONÇALVES, José Reginaldo Santos. O patrimônio como categoria de pensamento. Comunicação apresentada na mesa redonda "Patrimônios emergentes e novos desafios: do genérico ao tangível" durante a $26^{\text {a }}$ Reunião Anual da Associação Nacional de Pós Graduação em Ciências Sociais realizada em Caxambu em 23 de outubro de 2012.

LANNA, Marcos P.D. A Dívida Divina. Troca e patronagem no Nordeste Brasileiro. Campinas-SP: Editora da Unicamp. 1995.

LE GOFF, Jacques. História e Memória. Campinas-SP: Editora da UNICAMP, 2003.

LEITE LOPES, José Sérgio. A tecelagem dos conflitos de classes na cidade das chaminés. Brasília-DF: Ed Marco Zero e Ed. UnB, 1988.

O Vapor do Diabo: o trabalho dos operários do açúcar. Rio de Janeiro: Paz e Terra, 1976.

MACÊDO, Muirakytan K. A Penúltima versão do Seridó - Uma história do regionalismo seridoense. Natal: EDUFRN, 2012. 
MARX, Karl. O Capital: crítica da economia política. Tradução por Reginaldo Sant'Anna. Rio de Janeiro, Civilização Brasileira, 1968. Livro 1: O processo de produção capitalista, 2 v. (Col. Perspectivas do Homem, 38-A)

MEAD, Margaret. Sexo e temperamento em três sociedades primitivas. São Paulo: Perspectiva, 1979.

MORAIS, Marcus César Cavalcanti de. Terras Potiguares. Natal: Dinâmica Editora, 1998.

NESI, Júlio de Resende. Uma análise preliminar da ascensão e queda da produção da scheelita e wolframita no Brasil no período de 1943 a 1993. Natal, 1994. Mimeo. Trabalho apresentado no $38^{\circ}$ Congresso Brasileiro de Geologia. Camboriú, 23 a 28 de outubro de 1994.

PARK, Robert Erza. A cidade: sugestões para a investigação do comportamento humano no meio urbano. In: Velho, O. G. (org.). O Fenômeno Urbano. Rio de Janeiro, Zahar Editores, 1987.

POLLAK, Michael. Memória e identidade social. Estudos Históricos. V. 5, nº 10: 200-212. Rio de Janeiro: Associação de Pesquisa e Documentação Histórica (APDOC), 1992.

SIMMEL, Georg. A natureza sociológica do conflito, in Moraes Filho, Evaristo (org.), Simmel, São Paulo, Ática, 1983.

SPIVAK, Gayatri Chakravorty. ¿Puede Hablar El Subalterno? Revista colombiana de Antropologia, (39), 2003. Pp. 297-364.

THOMPSON, Edward P. A formação da classe operária inglesa. Vol. I, II e III, Paz e Terra, São Paulo. 2004.

VELHO, Otavio Guilherme. Capitalismo autoritário e campesinato. Rio de Janeiro: Zahar, 1976.

WILLIAMS, Raymond. Marxismo e literatura. Rio de Janeiro: Zahar Editores, 1979.

WOORTMANN, K. "Com parente não se neguceia": o campesinato como ordem moral. In: Anuário Antropológico, EdUnB/Tempo Brasileiro, Rio de Janeiro, 1991. Pp. 11-73.

\section{Cinematografia}

CARVALHO, Vladimir. A pedra da riqueza. 1976.

\section{Website}

http://tribunadonorte.com.br/noticia/a-mina-possui-um-bom-potencial/155099. Acesso em 03/03/14.

Recebido em: 10/09/2014

Aprovado em: 07/11/2014 